\title{
Sovereign Debt Crises and Credit to the Private Sector
}

\author{
Carlos Arteta \\ Board of Governors of the Federal Reserve System \\ Galina Hale \\ Federal Reserve Bank of San Francisco
}

December 2006

Working Paper 2006-21

http://www.frbsf.org/publications/economics/papers/2006/wp06-21bk.pdf

The views in this paper are solely the responsibility of the authors and should not be interpreted as reflecting the views of the Federal Reserve Bank of San Francisco or the Board of Governors of the Federal Reserve System. This paper was produced under the auspices of the Center for Pacific Basin Studies within the Economic Research Department of the Federal Reserve Bank of San Francisco. 


\title{
Sovereign Debt Crises and Credit to the Private Sector
}

\author{
Carlos Arteta \\ Board of Governors of the Federal Reserve System \\ Galina Hale* \\ Federal Reserve Bank of San Francisco
}

December 15, 2006

\begin{abstract}
We use micro-level data to analyze emerging markets' private sector access to international debt markets during sovereign debt crises. Using fixed effect analysis, we find that these crises are systematically accompanied by a decline in foreign credit domestic private firms, both during debt renegotiations and for over two years after the restructuring agreements are reached. This decline is large (over 20 percent), statistically significant, and robust when we control for a host of fundamentals. We find that this effect is concentrated in the nonfinancial sector and is different for exporters and for firms in the non-exporting sector. We also find that the magnitude of the effect depends on the type of debt restructuring agreement.
\end{abstract}

JEL classification: F34, F32, G32

Key words: sovereign debt, debt crisis, credit rationing, credit constraints

\footnotetext{
${ }^{*}$ Corresponding author. Contact: Federal Reserve Bank of San Francisco, 101 Market St., MS 1130, San Francisco, CA 94105, galina.b.hale@sf.frb.org. We thank two anonymous referees, Paul Bedford, Doireann Fitzgerald, Oscar Jorda, Enrique Mendoza, Paolo Pasquariello, Kadee Russ, Jose Scheinkman, Diego Valderrama, seminar participants at Federal Reserve Bank of San Francisco, Stanford, UC Davis, Cornell, University of Michigan, and the participants at LACEA 2005 and AEA 2006 meetings for helpful comments. We are grateful to Emily Breza, Chris Candelaria, Rachel Carter, Yvonne Chen, Heidi Fischer, and Damian Rozo for outstanding research assistance at different stages of this project. We thank Peter Schott for providing export data. All errors are ours. The views in this paper are solely the responsibility of the authors and should not be interpreted as reflecting the views of the Board of Governors of the Federal Reserve System or any other person associated with the Federal Reserve System.
} 


\section{Introduction}

In the last two decades of the 20th century, emerging markets experienced a lending boom. Not surprisingly, this boom was accompanied by a number of sovereign debt restructuring episodes, many of which were followed by economic crises of varying severity in the affected countries. One channel through which economic activity can be affected by sovereign debt restructuring is the tightening of external financial constraints for the private firms. This may be an important channel, because international capital market has become an important source of funds for the emerging markets' private sector. Throughout the lending boom, private sector borrowing accounted for over $30 \%$ of total net capital inflows to emerging markets 11 Now about $25 \%$ of emerging markets' corporate bonds and bank credit are external, and this number is much larger for Latin American emerging economies: ${ }^{2}$

To our knowledge, this paper presents the first systematic analysis of the effects of sovereign debt crises on the foreign credit to the private sector. Recent empirical work has found various changes in private sector credit patterns in the aftermath of financial crises (Blalock, Gertler, and Levine, 2004; Desai, Foley, and Forbes, 2004; Eichengreen, Hale, and Mody, 2001; Tomz and Wright, 2005) as well as changes in stock market behavior (Kallberg, Liu, and Pasquariello, 2002; Pasquariello, 2005). The empirical literature regarding the effects of sovereign debt crises has focused on the impact on sovereign borrowing $!^{3}$ We focus on the short- and medium-run effects of sovereign debt crises on private firms' access to foreign credit. In our exercise, we do not estimate the probability of sovereign debt crises; instead, we take these events as given and analyze their ex

\footnotetext{
${ }^{1}$ See, for example, Chapter 4 of Global Development Finance, The World Bank, 2005.

${ }^{2}$ See Chapter 4 of the Global Financial Stability Report, IMF, April 2005.

${ }^{3}$ Eichengreen and Lindert (1989) find that sovereign default does not seem to influence future access of sovereigns to the capital market. This finding is confirmed in a recent study by Gelos, Sahay, and Sandleris (2004) — they find that the probability of the sovereign's market access is not strongly influenced by the sovereign default. On the other side of the debate, Ozler (1993) claims that the countries can only reenter the credit market after settling old debts, and Tomz and Wright (2005) find that over the last 200 years "about half of all defaults led to exclusion from capital markets for a period of more than 12 years."
} 
post effects.

Debt restructuring is not a discrete event, but rather a process that in many cases involves a substantial period of time. Because it is possible that the response of both borrowing firms and foreign investors is different during debt renegotiations than it is after the final restructuring agreement, we construct data on the onset of debt renegotiations and consider separately the effects of the renegotiations and the effects of reaching the restructuring agreement. We also analyze the effects of different types of debt restructuring agreements.

Sovereign debt crisis can lead to reduced foreign credit to private domestic firms via the decline in supply, as lenders' perceptions of country risk worsen (Drudi and Giordano, 2000), via the decline in aggregate demand that is triggered by a sovereign debt crisis and its resolution (Dooley and Verma, 2003; Tomz and Wright, 2005), and via exogenous shocks that affect both the probability of sovereign debt crisis and the amount of foreign credit to the private sector. We provide an intuitive discussion of these channels. While our empirical methodology does not allow us to distinguish between the demand and the supply effects, we address the possibility of a common shock.

Our micro-level data on foreign bond issuance and foreign syndicated bank loan contracts come from Bondware and Loanware and cover 30 emerging markets between 1984 and 2004 4 We group privately owned firms into financial and nonfinancial sectors and split the latter into exporting and non-exporting sectors using information on the export structure of the country $5^{5}$ For each sector, we calculate the total amount that firms borrowed in the bond market or from bank syndicates in each month. We also construct a number of indicators that describe various aspects of each country's economy as well as factors that affect the world supply of capital to emerging markets,

\footnotetext{
${ }^{4}$ Hale (2007) shows that sovereign debt restructuring has a large impact on the instrument composition of private borrowers' external debt. Thus, we are combining bond and bank financing to account for possible substitution between the instruments.

${ }^{5}$ We attempted to split our sample according to an industry's financial dependence (Rajan and Zingales, 1998). Unfortunately, financial dependence data are available only for the manufacturing sector, which will make us lose more than a half of our sample.
} 
which we use as control variables. We analyze these data using fixed effects panel regressions.

We find systematic evidence of a decline in foreign credit in the aftermath of sovereign debt crises ${ }^{6}$ All the effects are statistically significant and economically important: After controlling for the effects of fundamentals, we find an additional decline in credit of over $20 \%$ below the country-specific average during the debt renegotiations, which persists more than two years after the restructuring agreement is reached. In our analysis of different types of debt restructuring agreements, we find that the decline in foreign credit to the private sector is smaller after agreements with commercial creditors as opposed to agreements with official creditors and that no decline occurs after voluntary debt swaps and debt buybacks. Furthermore, agreements that include new lending lead to a lower decline in credit to the private sector than agreements that do not.

The distribution of this decline is uneven across firms: Credit to the exporting sector is not affected during the debt renegotiations but declines after the agreement is reached, while credit to the non-exporting sector declines during the renegotiations and then recovers within a year after the agreement is reached; credit to the financial firms also declines after the agreement is reached but by a small amount that is not statistically different from zero. Our tentative explanation for these findings is an information story in which lenders have different amounts of information about different types of borrowers and engage in relationship lending: 7

It is worth emphasizing that in focusing on foreign debt financing of emerging market private firms, we do not analyze capital flows that occur in the form of trade credit, foreign direct investment (FDI), or funds raised on the stock market. $8^{8}$ We also exclude multinational and foreignowned companies from our sample. Thus, our results are limited to foreign borrowing by private

\footnotetext{
${ }^{6}$ In order to capture country risk premium properly, we exclude from the analysis all foreign owned firms.

${ }^{7}$ For a similar mechanism discussed in the literature on geographic location of borrowers and lenders, see DeYoung, Glennon, and Nigro (2006) and references therein.

${ }^{8}$ Auguste, Dominguez, Kamil, and Tesar (2006) show that after the most recent crisis in Argentina, firms successfully raised funds through ADRs. In a systematic analysis Arslanalp and Henry (2005) find that when countries announce debt relief agreement under Brady Plan, their stock markets experience a sustained appreciation.
} 
domestically owned firms.

Our findings represent a step towards understanding the costs of sovereign debt crises. Recent models of financial crises in general and debt crises in particular assume that debt crises are costly, particularly in terms of cost of capital (Arellano, 2004; Arellano and Ramanarayanan, 2006; Yue, 2005), but there is very little empirical evidence on the nature of these costs $9^{9}$ Our paper provides a justification for the assumption of costly debt crises as well as and a set of observations that might facilitate explicit modeling of such costs.

The remainder of the paper is organized as follows. In Part 2 we discuss the channels through which sovereign debt crises can affect private firms' foreign borrowing. Part 3 describes the empirical approach and the data. Part 4 presents the results of the empirical analysis and their relation to the mechanism of the transmission of debt crisis effects to the private external borrowing. Part 5 concludes.

\section{Sovereign debt crises and lending to the private sector}

In this section we provide an intuitive discussion of the channels through which sovereign debt crises can affect foreign credit to domestically owned private firms. We focus on the short-run effects and do not discuss structural changes in the economy, such as entry or exit in certain sectors, or fire-sale FDI activity.

\subsection{Causal effects}

When the sovereign starts debt renegotiations, whether or not it formally announces its inability to service the debt, investors might perceive the country risk to be higher and raise the risk premium

${ }^{9}$ For the empirical work on the cost of capital in emerging markets, see Perri and Neumeyer (2005) and Uribe and Yue (2006). 
they charge all the borrowers from the country (Drudi and Giordano, 2000). In fact, in many cases credit rating agencies follow a "sovereign ceiling" practice, according to which no private borrowers can obtain a better rating than their sovereign. Thus, credit would become more expensive for all domestic firms and firms would decrease their borrowing 10 The size of the decline in credit will depend on the price elasticity of demand for credit. One would expect that financial and exporting sectors would be more responsive to the changes in the cost of credit: financial firms can rely on domestic liabilities such as deposits or can reduce their lending, while exporters can finance themselves through trade credit.

There is, however, a possibility of an offsetting effect. When a sovereign starts renegotiations of the debt, it is unlikely to be able to issue any new debt until the deal is settled. During this time investors might want to lend to the country for diversification reasons and thus might actually increase their supply of credit to the private sector.

After the restructuring agreement is reached, the period of recovery from the debt crisis starts. Depending on the terms of the agreement, the country risk premium might fall or rise compared to what it was during the renegotiation period: on the one hand, the uncertainty regarding the terms of restructuring is resolved, which will always lead to a decline in the risk premium, ceteris paribus; on the other hand, the terms of the agreement could change investors' assessment of the probability of future debt crises and of their losses in case the crisis occurs. If the "haircut" (or the reduction in the present value of the debt) is too high, investors would expect higher losses in the future, and if the haircut is too low, they will expect that the sovereign will again have problems servicing its debt. In either case, the country risk premium might actually go up after the agreement is reached 11 and the amount of credit will decline even further.

In practice, sovereign debt crises are frequently accompanied by a decline in aggregate demand

\footnotetext{
${ }^{10}$ The empirical literature shows that foreign debt restructuring by a sovereign may lead to persistent worsening of the terms of future borrowing for all ownership sectors (Hale, 2007; Ozler, 1993; Tomz and Wright, 2005).

${ }^{11}$ See Sturzenegger and Zettelmeyer (2005) and (2006) for a presentation of the history of "haircuts" and other details of debt restructuring episodes.
} 
(Dooley and Verma, 2003; Tomz and Wright, 2005). This could be due to a current or expected monetary and fiscal tightening, to the conditionality that IMF involvement in the crisis resolution usually carries, or to an exogenous shock that leads to both sovereign debt crises and to a decline in aggregate demand. We discuss the latter possibility in the next section.

Whatever the mechanism, the decline in aggregate demand may lead to a decline in the demand for goods and services, especially for firms in the non-exporting sector ${ }^{12}$ This decline in demand will lead to two effects: First, firms are likely to experience a decline in profits that would lead to a decline in their net worth, which, in the credit rationing environment, will tighten their borrowing constraints ${ }^{13}$ Second, the firms are likely to accumulate inventory and produce less next period, which means they will demand less credit. They will also use fewer inputs, which will push the price of inputs down and lower the input costs, and therefore further lower their demand for credit.

Sovereign debt crises are frequently accompanied by domestic banking crises, usually because the government postpones debt restructuring talks and strains the banking system in order to service the debt until doing so is no longer feasible. This would make domestic liquidity more scarce and would increase demand for foreign credit both from the banking system and from nonfinancial firms that find it difficult to borrow domestically ${ }^{14}$

Some sovereign debt crises are also accompanied by currency collapses. Abstracting from the long-run effects of these currency collapses, we focus on the accounting effect of large changes

\footnotetext{
${ }^{12}$ Since there is no evidence of direct trade sanctions imposed in the aftermath of sovereign defaults (Martinez and Sandleris, 2004), the decline in demand for the exports is less likely to occur. Rose (2005), on the other hand, finds that, in the long run, debt renegotiations do lead to a decline in trade. In addition, as Helpman (2006) points out, firms that export only export a small fraction of their output, and, therefore are also likely to be affected by a decline in domestic aggregate demand.

${ }^{13}$ Sandleris (2005) derives these effects in a context of endogenous sovereign default. See Stiglitz and Weiss (1981), Calomiris and Hubbard (1990), and Mason (1998) for models of credit rationing and net worth. See Arellano, Bai, and Zhang (2006), Mendoza (2006) and Schneider and Tornell (2004) for the models of borrowing constraints in the context of financial crisis.

${ }^{14}$ For a formal treatment of the interplay between domestic and foreign lending, see Caballero and Krishnamurthy (2002).
} 
in the real exchange rates 15 First, if most of the firms' costs are denominated in the domestic currency, they will have to borrow less in foreign currency in order to obtain the same amount in domestic currency. Since most foreign lending is denominated in "hard" currencies (Eichengreen and Hausmann, 1999; Eichengreen, Hausmann, and Panizza, 2002), this would mean a decline in demand for foreign credit. In addition, exporting firms will experience a decline in their domestic input costs relative to their foreign sales (which are denominated in foreign currency (Goldberg and Tille, 2005)). This decline would lead to an increase in their profits and retained earnings and would allow them to borrow less, i.e., demand less credit. On the other hand, domestic firms that use imported intermediate goods will experience an increase in their input costs and will therefore demand more credit. Finally, firms with liabilities denominated in foreign currencies that sell in domestic markets will experience balance sheet effects, which would immediately lead to a decline in their net worth and tighten their borrowing constraints. Thus, currency depreciation would also lead to a decline in the supply of credit to non-exporting firms.

Thus, a sovereign debt crisis can lead to a decline in foreign credit to the private sector through both a decline in the supply of credit and through a decline in the demand for credit. In this paper, due to data limitations, we do not attempt to disentangle the demand and the supply effects, but rather estimate a reduced form model of the effects of sovereign debt crises on the amount of foreign credit obtained by private sector firms. However, we try to isolate some of the channels discussed above by controlling for the state of the economy (through a set of indexes), for the presence of the IMF agreement, for banking crises, and for changes in real exchange rate.

\footnotetext{
${ }^{15}$ Burstein, Eichenbaum, and Rebelo (2002) and (2004) show that domestic prices adjust very slowly after a currency collapses, and, therefore, real and nominal exchange rates move closely together in the short run.
} 


\subsection{Common shocks}

A decline in foreign credit to the private sector could also be due to a shock that simultaneously triggers a sovereign debt crisis ${ }^{16}$ For example, an adverse aggregate demand or productivity shock would decrease the private sector's demand for credit, as described above, and at the same time lead to a decline in government revenues and therefore to a sovereign debt crisis.

Furthermore, both a sovereign debt crisis and a decline in credit to the private sector could result from a sudden stop in foreign capital inflows into the country (Calvo, 1998). In this case, the decline in credit to the private sector would be due to a decline in the supply of credit to the country as a whole, rather than to a decline in a demand for credit by individual private firms.

In both cases, a common shock would create an association between debt renegotiations and foreign credit to the private sector. It is unlikely, however, that a common shock would lead to the same simultaneity problem between the restructuring agreement and the foreign credit to private sector, since the timing of the restructuring agreement depends predominantly on the renegotiation progress.

Since we are interested in the causal relationship between sovereign debt crises and foreign credit to private sector, we do our best to control for common shocks in two ways: first, including a set of aggregate demand variables (collected into indexes) and the indicator for systemic sudden stops (Calvo, Izquierdo, and Talvi, 2006) as control variables in our fixed effects regressions ${ }^{17}$ and, second, using treatment effects methodology, described in Section 4.4.

\footnotetext{
${ }^{16}$ See Aguiar and Gopinath (2006), Arellano (2004), and Yue (2005) for models of sovereign default due to an exogenous adverse shock. They also show that the same shock leads to a decline in the country's borrowing, although they do not distinguish between the private and the public sectors.

${ }^{17}$ Due to the potential endogeneity of the sudden stop variable, we do not include it in our main specification, but analyze its effect in our robustness tests. The results of the main specification are not affected by the addition of the systemic sudden stop control variable.
} 


\section{Empirical approach and data sources}

The previous section discussed the channels through which sovereign debt crises might affect private sector foreign borrowing. We now turn to empirical analysis of this relationship. We look at different measures of credit, as well as various types of debt restructuring agreements.

In order to test for a decline in credit in the aftermath of a sovereign debt restructuring, we estimate the following reduced-form equation, using regressions with fixed effects:

$$
q_{i t}=\alpha_{i}+\alpha_{t}+\beta_{0} d_{i t}+\beta_{1} n_{i t}+\gamma_{0} r_{i t}+\sum_{\tau=1}^{K} \gamma_{\tau} z_{\tau i t}+\mathbf{X}_{\mathbf{i t}}^{\prime} \eta+\varepsilon_{i t}
$$

where $q_{i t}$ is a measure of credit, $\alpha_{i}$ is a set of country fixed effects absorbing the effect of initial conditions, $\alpha_{t}$ is a set of year fixed effects absorbing the effect of common trend, $d_{i t}$ is an indicator of a month in which debt renegotiations start, $n_{i t}$ is an indicator of each month during which renegotiations continue, $r_{i t}$ is an indicator of a restructuring agreement month, $z_{\tau i t}$ is an indicator that a restructuring agreement occurred more than $\tau-1$ but less than $\tau$ years ago (we set $K=3$ ) ${ }^{18}$ $\mathbf{X}_{\mathbf{i t}}$ is a set of control variables, and $\varepsilon_{i t}$ is a set of robust errors clustered on country. Specific definitions of all these variables are below. Data sources are described in detail in Table 9 .

To test whether there is an immediate dampening of the effect after the restructuring agreement, in the above regression we replace $z_{1 i t}$ 's with the $m_{\text {sit }}$ 's which indicate that the restructuring occurred exactly $\varsigma$ months ago. We include up to 11 months in the regressions, since further effects are captured by the $z_{\tau i t}$ 's, $\tau=2,3$. To see if the expectations of debt crisis play a role, we include up to 12 monthly leads in the regression as well.

\footnotetext{
${ }^{18}$ Higher lags are estimated less precisely due to a small number of cases in which the gap between different episodes of renegotiations and restructuring is over 3 years. Setting $K=4$ does not affect the results.
} 


\subsection{Sovereign debt renegotiations and restructuring episodes: $d_{i t}, n_{i t}, r_{i t}$}

The data on the dates of actual agreements on debt restructuring are readily available from the Paris Club and the World Bank's Global Development Finance (2002), which describe all restructuring episodes of commercial and official debt that occurred between 1980 and 2000, which we supplemented with data from subsequent issues of the Global Development Finance. These data include the terms of restructuring. In addition to negotiated restructuring episodes, the World Bank data include voluntary debt swaps and debt buybacks, which are also included in our sample 19 These data also allow us to differentiate between the agreements that include new loans and the ones that do not.

The dates of the onset of renegotiations are not readily available. We trace them in the financial news using the Lexis-Nexis database. We search for the first mention of the sovereign debt renegotiation prior to each restructuring episode in any English-language media. The number of these renegotiation episodes and the number of debt restructuring agreements for the countries in our sample are reported in Table 1. This table also shows how many of the restructuring episodes were voluntary debt swaps and buybacks executed at market values, how many episodes were agreements with commercial creditors, and how many episodes included new lending ${ }^{20}$ Note that the number of renegotiations is substantially smaller than the number of agreements. This is due to two factors: first, some debt has been restructured more than once, and second, some restructuring episodes such as swaps and buybacks were not preceded by a period of publicly known renegotiations.

\footnotetext{
${ }^{19}$ As such, our definition of a restructuring episode is much broader than that used in Reinhart, Rogoff, and Savastano (2003), Reinhart and Rogoff (2004), and Tomz and Wright (2005).

${ }^{20}$ For a detailed description of big sovereign debt crises in the 1990s, see Sturzenegger and Zettelmeyer (2006).
} 


\subsection{Credit to financial, exporting and non-exporting sectors: $q_{i t}$}

From Bondware and Loanware data sets, we gather all foreign bond issues and foreign syndicated loan contracts obtained by emerging market firms between January 1981 and August 2004 ${ }^{21}$ Importantly, these do not include trade credit. For bonds issued through off-shore centers, we trace the true nationality of the borrower by the location of their headquarters. We exclude all the firms that are owned by the government or by multinational or foreign companies ${ }^{22}$ For each firm in these data sets, we code whether or not it is in the financial sector; and, for nonfinancials, whether or not it is in the exporting sector, using the export structure of a country and the borrower's industry of activity at a 4-digit SIC level.23 As Helpman (2006) points out, not all the firms in the exporting sector will export, suggesting that our method of coding firms into exporting and non-exporting is imprecise. Given the available data, however, this was the best we could do. If we miscode non-exporters as exporters (the error is unlikely to go the other way), we would be less likely to find the difference between the two sectors downward. We also believe that the firms that have direct access to foreign capital markets tend to be larger and more profitable and therefore are more likely to export.

We then aggregate the amounts (measured in U.S. dollars) of bond issues and of loans for each sector-country-month. We drop from our analysis countries for which the total amount of bonds and loans for all three sectors was non-zero in fewer than 24 months out of 264 months in our data sample. This ensures that we have enough identifying observations for each country, and leaves us with the 30 countries listed in Table 1 . Figure 1 and Table 2 summarize the amount borrowed by each sector in our sample.

\footnotetext{
${ }^{21}$ Bond data start in March 1991.

${ }^{22}$ Desai, Foley, and Forbes (2004) find that multinationals expand their activities and credit as a result of currency depreciation.

${ }^{23}$ The export structure is obtained from (Feenstra, Romalis, and Schott, 2002). Table 4 presents sample industries in exporting and non-exporting sectors. Some industries appear in both columns, because they represent exports for some countries, but not for the others.
} 
We divide each amount by the U.S. consumer price index (CPI) to obtain the amount of credit for each sector-country-month in real dollars. We then construct our dependent variables as a percentage deviation from the country-specific average for each of the sectors. ${ }^{24}$ Due to the high frequency of debt crises in some countries, we do not exclude crisis periods from our means, which biases the means downwards; therefore, the effects we find may be smaller than the true ones.

\subsection{Control variables: $\mathrm{X}_{\mathrm{it}}$}

The control variables are indexes that describe different dimensions of the economy ${ }^{25}$ In each case, the variables are used as percentage deviation from their 25-year country-specific average from 1980 to 2004 on a monthly basis. All the indexes described below, with the exception of global supply of capital indexes, are lagged by one month. 26

Since many of the variables we would like to control for are highly correlated, we construct the indexes using the method of principal components. Because a principal component is a linear combination of the variables that enter it, in cases when some variables are missing, other weights can be re-scaled to compensate for missing variables. In this way, some of the gaps in the data may be filled, which in our case is a main advantage of using these indexes.

We group the variables in the following categories, summarized in Table 3 . The linear combinations are reported in the Appendix.

- International competitiveness. A country's international competitiveness affects the prof-

\footnotetext{
${ }^{24}$ We use percentage deviations from the country-specific sample means for all continuous variables. Differences in means are captured by country fixed effects, while common trends are captured by year fixed effects. We do not exclude country-specific trends in variables because the measured trends are affected by sovereign debt crises and excluding them will mask the debt crises effects.

${ }^{25}$ We draw on the broad empirical literature on emerging market spreads to select our variables (Eichengreen, Hale, and Mody, 2001; Eichengreen and Mody, 2000a; Eichengreen and Mody, 2000b; Gelos, Sahay, and Sandleris, 2004; Kaminsky, Lizondo, and Reinhart, 1998; Mody, Taylor, and Kim, 2001).

${ }^{26}$ This turns out not to make much difference in our estimates compared to the case when they are not lagged or when they are lagged one year. The main reason we lag the indicators is because flow variables entering the indexes are calculated for the entire month, while the negotiations could have started towards the beginning of the month.
} 
itability of firms in both the export and the import substitution sectors and therefore their demand for credit. It also reflects a country's ability to bring in enough foreign currency to service its foreign debt and thus will affect foreign investors' interest in the country. The following variables are used to construct the index: terms of trade, change in current account, index of the market prices of the country's export commodities ${ }^{27}$ change in real exchange rate, and volatility of export revenues. This index is scaled by a measure of trade openness the ratio of trade volume (sum of exports and imports) to GDP. Two principal components are retained for this index.

- Investment climate and monetary stability. This index accounts for the short-run macroeconomic situation in the country. It reflects demand for investment, the availability of domestic funds, and foreign investors' interest in the country. This index is constructed using the following variables: sovereign credit risk, measured by the Institutional Investor credit rating, ratio of debt service to exports, ratio of investment to GDP, real interest rate, ratio of lending interest rate to deposit interest rate, inflation rate, ratio of domestic credit to GDP, and change in domestic stock market index. Three principal components are retained for this index.

- Financial development. The level of development of the financial market affects domestic funding opportunities for firms and, therefore, their demand for foreign credit, and their ability to service foreign debt. This index is based on the ratio of stock market capitalization to GDP, the ratio of commercial bank assets to GDP, and the degree of financial account openness, which reflects how easy it is for firms to access foreign capital directly. Only the

\footnotetext{
${ }^{27}$ Many emerging markets rely heavily on the export of a small number of commodities. We identify up to five of these commodities (or commodity groups) for each country and merge these data with monthly commodity prices from the Global Financial Data and the International Financial Statistics. For each commodity, we calculate monthly percentage deviations from its 25-year average (1980-2004). For each country and each month, we construct the index as a simple average of relevant deviations of commodity prices. If a country is exporting a variety of manufactured goods and does not rely on commodity exports, this index is set to zero.
} 
first principal component is retained for this index. ${ }^{28}$

- Long-run macroeconomic prospects. The economy's growth prospects affect the investment demand of firms and the investors assessment of the country risk. This index is based on the ratio of total foreign debt to GDP, the growth rate of real GDP, the growth rate of nominal GDP measured in U.S. dollars, and the unemployment rate. The first two principal components are used.

- Political stability. When the political situation in a country is unstable, it introduces uncertainty and leads to a decline in firms' investment and their demand for credit; furthermore, it may lead to foreign investors' concerns about their ability to collect their assets in the future. This index is adopted directly from the International Country Risk Guide (ICRG).

- Global supply of capital. This index reflects the availability of capital in general, changes in investors' risk attitude, and their willingness to provide capital to emerging markets. This index is constructed on the basis of an investor confidence index ${ }^{29}$ the growth rate of the U.S. stock market index, the U.S. Treasury rate, the volume of gross international capital outflows from OECD countries, and Merrill Lynch High Yield Spreads. All variables are presented as percentage deviations from their 25-year average. Two principal components are retained and capture $65 \%$ of the variance.

In addition to these indexes, we include explicitly the real exchange rate, because it can affect the amount of borrowing measured in foreign currency directly, through the accounting effects described above ${ }^{30}$ To control for the effects of banking crises that sometimes accompany sovereign debt crises, we include an annual banking crisis indicator (Hutchison and Noy, 2005).

\footnotetext{
${ }^{28}$ Chinn and Ito (forthcoming) show that, in fact, financial openness and financial development tend to be correlated.

${ }^{29}$ Yale School of Management Stock Market Confidence Indexes can be obtained from the Yale SOM web site.

${ }^{30}$ Nominal exchange rates were obtained from various data sources. For countries that changed the denomination of their currency, continuous series were constructed to reflect true changes in currency values.
} 
Some creditors are not able or willing to lend to the countries that do not have an IMF agreement in place, therefore, supply of credit to these countries can be adversely affected, especially in the aftermath of sovereign debt crisis. We set this variable equal to one if either a standby or an extended funds facility is in place for each month for a given country. Since the IMF funding is extended to sovereigns, they might affect sovereign demand for funds from commercial creditors, but are not likely to affect private demand for foreign credit directly .

\section{Empirical findings}

We analyze whether there is a reduction in credit due to sovereign debt crises. We first focus on the medium run, including our main explanatory variable for up to three years. We then repeat the analysis with monthly indicators of the event.

The size of the coefficients in all regressions can be easily interpreted. The "impact" coefficient represents the size of the percentage change in credit relative to what it would have been without the renegotiations or restructuring agreement in a given month. The coefficients on the annual indicators represent the size of the percentage change in credit in each month of the year $\tau$ since the debt restructuring agreement, assuming this change was constant throughout the year, relative to what it would have been otherwise.

\subsection{Main results}

The results for the most broadly defined debt restructuring episodes and for the total borrowing by all sectors are presented in Table 5. The first column presents a regression that does not include any variables associated with sovereign debt crises and is just the test of our specification with respect to control variables. All the regressions in the table include year and country fixed effects. We can see that with the fixed effects included, the first two groups of indexes do not have a significant 
effect. Overall, our model explains $20 \%$ of the variance in the fluctuations of private borrowing.31

All subsequent regressions include our variables of interest. The second column presents a regression with only debt renegotiations and restructuring variables on the right-hand side. We can see that the credit declines immediately in the month the renegotiations begin, although this coefficient is not significant, then falls further during the renegotiations, by about $30 \%$, and even further, by an additional $14 \%$ in the first year after the restructuring agreement is reached. It recovers a third of the way in the second year and another third in the third year.

Column (3) adds our control variables, or "fundamentals." We can see that part of the decline in credit found in column (2) is due to worsening of the fundamentals - the decline in credit during debt renegotiations is just below $20 \%$, which worsens to a $30 \%$ decline after the agreement is reached. The recovery pattern appears to be slower when we control for the fundamentals.

Figure 2 presents the coefficients, based on the model in column (3), on the sovereign debt renegotiations and restructuring variables that are included at monthly frequency with their individual confidence intervals. The F-tests below measure the probability that the sum of the coefficients is zero for each time period: before the crisis, during the period of renegotiations (between "talks" and "deal"), and after the restructuring agreement. We include 12 lead months (months before the start of debt renegotiations) in order to see if the debt crises were expected. We include up to 24 months of renegotiations (only 12 are represented on the graph), and 12 months with two additional annual dummies for the time after the agreement is reached 32

We find that there is no effect of the "expected" debt crises: credit prior to the start of debt

\footnotetext{
${ }^{31}$ This is a rather large share given that our left-hand side is measured in percentage deviations from the countryspecific means

${ }^{32}$ The picture represents an example of a timeline for the case when the renegotiations take exactly a year. In the cases when the renegotiations do not last as long, the "deal" line has to be moved to the left. If the renegotiations take longer, the line has to be moved to the right. Only 12 month are included because there are very few cases for which renegotiations take longer and therefore the confidence intervals are very large. The F-test is based on all 12 monthly coefficients and a dummy for the second year of renegotiations.
} 
renegotiations is actually higher than the mean 33 This positive effect could be due to excessive capital inflows into a country prior to sovereign debt crises (Arellano, 2004; Yue, 2005), as was the case in Mexico in 1994; or it could be simply due to the fact that crisis times are included in the means and therefore credit during "normal" times is higher than the mean by construction. We also see that there are no signs of recovering credit both during the renegotiations and for two years after the agreement is reached.

Even though our dependent variable is measured as a percentage deviation from the country mean, we are concerned that it might be persistent. In column (4) we allow for the AR(1) disturbance in the coefficients and find, reassuringly, that our point estimates and their significance levels are hardly affected by that change and that the estimated AR(1) coefficient is rather small at 0.08. We pursue this test further by including a lagged dependent variable on the right-hand side in column (5), and a country-specific lagged dependent variable in column (6). While we observe slight differences in the estimated coefficients, they are all within the same confidence interval as in our main specification (column (3)). This is not surprising, since the coefficients on the lagged dependent variable are small. In what follows, we will use the specification in column (3), which corresponds to equation (1), for our additional tests.

Before turning to more refined tests, we would like to summarize the insights we obtain from this estimation:

- In the aftermath of debt crises, the private sector experiences a $30-40 \%$ decline in foreign credit that persists for over two years.

- About a third of this decline is due to worsening fundamentals, banking system distress, currency depreciation, or the combination of these factors.

\footnotetext{
${ }^{33}$ As shown by the F-statistic, the sum of the monthly coefficient 12 months prior to the beginning of debt renegotiations is significantly different from zero at $8.4 \%$ level. When estimating the regression that restricts these coefficients to be the same, a year-lead indicator, we find that the coefficient is equal to 14.8 with $\mathrm{P}$-value of the t-test $8.6 \%$. Other coefficients in our baseline regression, Table 5 column (3), remain almost unchanged when we add this year-lead variable.
} 
- Controlling for fundamentals, banking crises, and the real exchange rate, the estimated decline in foreign credit to the private sector is about $20 \%$ during debt renegotiations, which increases to $30 \%$ in the first year after the agreement is reached, and is still around $20 \%$ in the third year after the debt restructuring agreement.

\subsection{Different sectors}

Table 6 and Figure 3 present the results of the reduced form estimation, where the left-hand side variable represents the total amount borrowed by a given sector of the economy. The sample and the specification is the same as in column (3) of Table 5 and equation (1). The dependent variable is now the borrowing by a particular sector of the economy rather than by all private firms 34

We find that the effects of sovereign debt crises are not the same for all the sectors of the economy. Column (1) presents the results of our estimation for the financial sector - none of the debt crisis coefficients are significantly different from zero. This result is not surprising given that we control for the banking crises and the real exchange rate. Conditional on the fundamentals, foreign investors would like to maintain their relationship with banks and other financial institutions even if the sovereigns have defaulted on their debt.

Column (2) presents the results for the entire nonfinancial sector. Since the entire private sector that we analyzed in Table 5 consists of only financial and nonfinancial firms, the effect that we find for the entire economy has to show up in the nonfinancial sector, since the financial sector appears to be unaffected. Indeed, we find that the decline in credit to nonfinancial firms is about the same order of magnitude as for the whole economy, both during the renegotiations and after the restructuring agreement is reached.

Columns (3) and (4) split nonfinancial firms into those that are in the exporting sector, and those that are in the domestic (non-exporting) sector. Interestingly, we find that the decline

\footnotetext{
${ }^{34}$ The number of observations varies slightly because not all sectors are equally represented in all countries.
} 
in credit to the nonfinancial sector during debt renegotiations is only due to a decline in the non-exporting sector. On the other hand, the decline in the aftermath of the debt restructuring agreement is entirely concentrated in the exporting sector.

It is relatively easy to make sense of the pattern we find for the non-exporting sector. Sovereign debt crisis increases uncertainty and tends to lower aggregate demand, thus negatively affecting both demand for credit by non-exporting firms and the supply of credit to them, as we discussed above. When the agreement is reached, the uncertainty is resolved and the aggregate output is likely to start recovering, restoring both demand and supply of credit for the non-exporting sector.

It is harder to understand the results we find for exporters. One potential explanation is that foreign lenders view exporters as more valued customers than the non-exporting sector. This could be because foreign banks tend to also have trade credit relationships with exporters and that exporters are able to supply some, albeit costly, collateral in the form of their international shipments. Thus, there is an option value to the banks for waiting until the uncertainty is resolved, which would explain the lack of decline in credit to exporters during the period of renegotiations. The decline in credit to exporters after the agreement is reached could imply that investors on average are not satisfied with the terms of the agreement and decrease their overall lending to the country.

We can summarize our findings in this section as follows:

- The decline in credit to the private sector in the aftermath of sovereign debt crises is entirely concentrated in the nonfinancial sector.

- Among nonfinancial firms, the firms that are in the non-exporting sector experience a decline of about $12 \%$ in credit during debt renegotiations, while exporters are not affected during this period.

- In the aftermath of the restructuring agreement, credit to non-exporting firms fully recovers, 
while credit to exporters declines by about $20 \%$ and stays at this low level for over two years.

\subsection{Types of debt restructuring}

In the above analysis we define debt restructuring quite broadly, including many varieties of debt reduction. It is reasonable to believe that voluntary debt swaps and debt buybacks by the government would not have the same effect as other forms of debt restructuring that involve maturity extension or a reduction in principal or interest payments. The agreements may affect investors' behavior differently depending on whether or not they include new credit. Finally, commercial and official debt restructuring may have different effects. We therefore estimate our model separately for different types of debt restructuring, for the entire private sector of the country. Again, we employ the same specification as in column (3) of Table 5 and equation (1). The results are reported in Table 7 .

In column (1), we include, in the same regression equation, separately the effects of buybacks and swaps and the effects of debt restructuring episodes that exclude buybacks and swaps (see column (3) of Table 1 for the number of buybacks and swaps for each country). We can see that our main results are driven by the debt restructuring agreements that do not include voluntary swaps and buybacks. Voluntary buybacks and swaps appear to be benign, if not beneficial: there is an increase in credit, although it is not statistically significant.

In column (2), we separate debt restructuring episodes into those that included new money (new credit), and those that did not (see column (5) of Table 1 for the number of the agreements that included new money, by country). Agreements that include new money have a smaller effect on private sector foreign borrowing. Possibly, the agreements that do not carry with them new loans contain a worse signal about a country's future creditworthiness and increase the country risk premium to a larger extent. In addition, this finding is consistent with the hypothesis discussed above that when no new credit accompanies debt restructuring, the economy might remain 
depressed for a longer period of time.

In column (3), we separate the effects of the agreements with commercial creditors from the effects of the agreements with official creditors (see column (4) of Table 1 for the number of commercial agreements by country). We find that official debt restructuring leads to a larger decline in credit than commercial agreements. A potential explanation for this result could lie in the timing of debt renegotiations - as a rule, official creditors negotiate with sovereigns before commercial creditors; thus, the agreement with commercial creditors contains no new information, especially if it just mimics the terms of the official agreement.

In a related paper, Arslanalp and Henry (2005) find that when countries announced debt relief agreement under the Brady Plan, they experience a stock market appreciation which successfully forecasted higher future resource transfer. Inasmuch as Brady deals were deals with commercial creditors and included both new money and buybacks of past debt, our results would predict that Brady deals would not lead to as much decline in credit to private sector as other debt restructuring agreements.

We can test for the effects of Brady deals explicitly, although there are only eight Brady deals in our sample ${ }^{35}$ Estimating a regression analogous to those reported in columns (1)-(3) of Table 7, with debt restructuring agreements separated into Brady and non-Brady, we find that the decline in credit in the first two years after Brady deals is $13-15 \%$ and is not statistically different from zero. We do find an increase of $25 \%$ in the third year after the agreement, but it is not statistically different from zero, either. Small number of Brady-type agreements is most likely responsible for the low precision of our estimates. Therefore, we find no contradiction between our results and those of Arslanalp and Henry (2005), although our methodology and sample are not powerful enough to confirm their results with certainty: ${ }^{36}$

\footnotetext{
${ }^{35}$ See Table 10.

${ }^{36}$ We must point out important differences between our paper and Arslanalp and Henry (2005): Our samples only intersect on seven Brady deals; We use the dates of final agreement, from the World Bank, while Arslanalp and Henry (2005) use the dates of agreement in principle, from the news sources; Arslanalp and Henry (2005) find no persistent
} 
In the last column, we analyze the effects of the agreements that are harmful by all three criteria: agreements with official creditors that do not include new money and are not voluntary swaps or buybacks (only 41 out of 155 agreements enter this estimation). Our goal here is to get an idea of the quantitative decline in credit after the "worst-case scenario" episodes. We find a decline in credit of over $40 \%$ that persists for as long as three years.

Thus, we find that countries that reschedule their official debt and do not receive new loans as a part of a debt restructuring agreement experience a larger decline in private external borrowing than the countries that reschedule their commercial debt, rely on buybacks and swaps and receive new loans as part of their restructuring agreement 37

\subsection{Common shocks and reverse causality}

As we discussed above, there is a possibility that the decline in foreign credit to private sector and sovereign debt crises are due to the same external shock and therefore the relationship we find above is not causal. We control for some of the potential common shocks (such as a decline in aggregate demand) in all our regressions through the use of the indexes.

Calvo (1998) argues that capital flows to a country could dry up for reasons not completely in control of the country. Such "sudden stops" would not necessarily occur in all countries, and therefore would not be captured by our measure of the global supply of capital. Thus, we include an indicator that is equal to one in each month a given country was affected by a systemic sudden stop in capital inflows, according to Calvo, Izquierdo, and Talvi (2006). Since this variable is missing for many countries, we do not include it in the main specification. Its addition does not affect the results of our estimation.

gains from Brady deals in the countries that do not stick to reforms, suggesting that it is a combination of reforms and Brady deals that is beneficial, while we condition on economic performance, removing its effect, which would lower positive estimated effects of Brady deals.

${ }^{37}$ Here and in all the regressions we control for country fixed effects. 
In addition, we apply treatment effects methodology to separate the causal relationship from common shocks (Cameron and Trivedi, 2005; Angrist and Krueger, 1999). We do this in two steps: first, we construct the propensity score using probit regression of the on-set of renegotiations on the real GDP growth rate, sudden stop indicator and two indexes describing the global supply of capital 38 The propensity score is then equal to the predicted probability of sovereign debt crisis. We next compare the amount of foreign credit to private sector for the observations with similar propensity score but different outcomes: the treatment group is the set of country-months that are in the process of debt renegotiations, the control group is the rest of observations, excluding the month of the beginning of renegotiations. We use, alternatively, stratified and kernel matching techniques. In all specifications we find that foreign credit to private sector is lower by $16-22 \%$, depending on specification, during the period of debt renegotiations. These estimates are all statistically significant at $1 \%$ confidence level.

We do not believe that the explicit reverse causality drives the results. Intuitively, it is unlikely that changes in the amount firms borrow internationally cause sovereign debt crisis. Statistically, in any specification we attempted, lagged values of the percentage change in the foreign credit to private sector do not have an effect on the probability of the on-set of debt renegotiations 39

\subsection{Robustness tests}

In this section we describe the robustness tests that we conducted. Table 8 presents some of the results. The rest of the results are not reported - they are available from the authors upon request.

In some cases, after financial crisis, the FDI activity increases, thus making the set of domestic firms smaller. Since we only include domestically owned firms in the analysis, we are concerned

\footnotetext{
${ }^{38}$ Our results do not depend on whether or not we us country and year fixed effects.

${ }^{39}$ We estimated probit and linear probability models with and without controls and with and without fixed effects for countries and years. We included up to three lags for the amount borrowed. The P-values for the coefficients on the lag amount borrowed range from 0.56 to 0.96 .
} 
that the total amount of credit would go down simply because there are fewer domestic firms. To address this issue, in columns (1) and (2) instead of using the total amount borrowed on the left-hand side, we analyze separately the changes in average size of a loan or a bond issue and the changes in the total number of loans or bond issues 40 We find that both the average amount (measured in U.S. dollars) and the frequency of borrowing fall substantially after sovereign debt crisis. This suggests that our results are not coming purely from the composition effect, in which case we would not observe the decline in the average size of the debt issue.

In order to see whether the accounting effects of currency depreciation are important and are not properly controlled for by including the real exchange rate, we analyze the total amount of credit measured instead in national currency units. The results are reported in column (3). We find that the results are very similar to those with credit measured in U.S. dollars (the appropriate comparison is Table 5 column (5)), although the coefficients are slightly smaller 41

To see if the effects are driven by the Russia-LTCM effects (Calvo and Talvi, 2005), we end our sample in 1998 (column (4)). We find that, although coefficients are slightly smaller than for the full sample, they are not significantly different. We lose significance for years 2 and 3 after the restructuring agreement since we lose the effects of restructuring episodes that occurred after 1995 - 50 out of 155 restructuring episodes in our sample.

To see whether the effects are different for different credit markets, we split the amounts borrowed by bonds and loans. We find that our results are driven entirely by the loan market, not surprising given the composition of private debt presented in Figure 1 and in Table 2, We decided to keep bonds in our future regressions in order to account for possible substitution effects between the two instruments.

\footnotetext{
${ }^{40} \mathrm{We}$ conduct this analysis for the nonfinancial sector only, since there is no observed decline in credit to the financial sector.

${ }^{41}$ In this regression we do not include the real exchange rate on the right-hand side, because we use the nominal exchange rate to calculate the amount borrowed denominated in national currency, since actual borrowing occurs in foreign currency.
} 
Since the results are driven by loans, we were worried that the debt crisis of the 1980s would have a disproportionate effect, since loans were the only credit instrument at that time. We find that this is not the case: When we limit our sample to the 1980s (column (5)), we find a decline in private credit only at the onset of debt renegotiations and no significant effects of debt restructuring. We think this is mostly due to the fact that foreign credit to the private sector was much less important during the 1980s (see Table 2). In fact, our results are driven mostly by the 1990s: when we reestimate our model for the sample that starts in 1991, when the bond market began to expand (column (6)), we find that the effects are slightly larger, but not statistically different from the full sample results.

Even though we include year dummies and control for the export commodity price index, we were worried that our results for exporters might be affected by the firms exporting oil and oilrelated products. We exclude all oil industry firms from our calculations of the amount borrowed and find that the decline in credit for exporters is less persistent, but otherwise the picture remains unchanged.

To examine whether the effects are driven by "serial defaulters," we excluded Argentina, Brazil, Mexico, Poland, and Russia from our sample 42 We find that our results continue to hold. When we instead limit our sample to these five countries, we find that the picture is still the same, although the coefficients are not significant for the most part. To see whether our results are driven by Latin America, we exclude all Latin American countries from the sample and find that the results are qualitatively the same.

We changed the content of the indexes in various ways. The results do not seem to be sensitive to these changes. We estimated the model with contemporaneous indexes rather than lagging them one month and found no significant changes. We also estimated the model with indexes 1-5 lagged one year and found no significant changes in our results.

\footnotetext{
${ }^{42} \mathrm{We}$ also experimented with excluding other countries, and found that no single country is driving our results.
} 
Finally, to test whether the heterogeneity of the data is driving the results, we estimated our model separately for each country and then averaged the estimated coefficients for each variable. All of the coefficients of interest are within the same confidence interval as in the main specification.

\section{Concluding remarks}

We empirically confirm that, during debt renegotiations and in the aftermath of restructuring agreements, foreign credit to emerging market private firms declines by over $20 \%$. We find that the negative impact of debt renegotiations and debt restructuring agreements varies by the type of borrower and is concentrated in nonfinancial sector. We find the differences in the response of credit to exporters and to non-exporting sector unexpected and intriguing, and believe they deserve theoretical investigation.

In addition to simply documenting the decline in private external borrowing in the aftermath of sovereign debt crises, this paper makes further empirical contributions by analyzing the effects of different types of debt restructuring and looking at different types of borrowers. In that, our findings not only provide justification for the assumption of costly sovereign debt crises frequently made in the literature, but also suggest some nuanced features an explicit model of such costs

should have. In particular, our findings point to the importance of information and uncertainty associated with sovereign debt crises.

Our findings suggest that taking into account the impact of sovereign debt crises on domestic firms is important: not only because of the direct costs associated with decline in foreign credit and therefore production in the economy, but also because such decline in credit can hamper future economic growth and therefore make subsequent debt crises more likely. However, bailing-out the sovereigns would not be a cure: even in cases when actual default was formally prevented through multilateral renegotiations, credit to the private sector declined before and after the agreement was 
reached. On the other hand, using voluntary forms of debt reduction did not lead to such adverse effects on credit to the private sector (these are usually not preceded by lengthy renegotiations).

It is important to note that we only focus on foreign credit provided to private firms. Moreover, our sample only includes firms that have direct access to foreign capital - firms that tend to be large. If their access to foreign capital is impaired, they are likely to turn to domestic banks, thus crowding out the credit to smaller firms. Thus, even though we do not consider small firms in our analysis, our results are suggestive of a decline in total credit in the economy and may partially explain the decline in economic activity observed after sovereign debt crises. 


\section{References}

Aguiar, M., and G. Gopinath (2006): "Defaultable Debt, Interest Rates and the CUrrent Account," Journal of International Economics, 69(1), 64-83.

Angrist, J. D., And A. B. Krueger (1999): "Empirical Strategies in Labor Economics," in Handbook of Labor Economics, ed. by O. Ashenfelter, and D. Card, vol. 3A, chap. 23, pp. 12771366. Elsevier.

Arellano, C. (2004): "Default Risk, the Real Exchange Rate and Income Fluctuations in Emerging Economies," Paper presented at the NBER IFM SI 2004.

Arellano, C., Y. Bai, and J. Zhang (2006): "Enforcement, Incomplete Contracts, and Recessions," mimeo, University of Minnesota.

Arellano, C., and A. Ramanarayanan (2006): "Default and the Term Structure in Sovereign Bonds," mimeo, University of Minnesota.

Arslanalp, S., And P. B. Henry (2005): "Is Debt Relief Efficient?," Journal of Finance, 60, $1017-51$.

Auguste, S., K. M. Dominguez, H. Kamil, and L. L. Tesar (2006): "Cross-Border Trading as a Mechanism for Capital Flight: ADRs and the Argentine Crisis," Journal of Monetary Economics, 53, 1259-1295.

Blalock, G., P. J. Gertler, and D. I. Levine (2004): "Investment Following a Financial Crisis: Does Foreign Ownership Matter?," Paper presented at SCCIE workshop on "Firms in Emerging Markets" May 20, 2005.

Burstein, A. T., M. Eichenbaum, and S. T. Rebelo (2002): "Why Are Rates of Inflation So Low After Large Devaluations?," NBER Working Paper No. W8748.

Burstein, A. T., M. Eichenbaum, and S. T. Rebelo (2004): "Large Devaluations and the Real Exchange Rate," NBER Working Paper No. W10986.

Caballero, R., and A. Krishnamurthy (2002): "A Dual Liquidity Model for Emerging Markets," American Economic Review, 92, 33-37.

Calomiris, C. W., and R. G. Hubbard (1990): "Firm Heterogeneity, International Finance, and 'Credit Rationing'," The Economic Journal, 100(399), 90-104.

Calvo, G. (1998): "Capital Flows and Capital Market Crises: The Simple Economics of Sudden Stops," Journal of Applied Economics, 1, 35-54.

Calvo, G., and E. Talvi (2005): "Sudden Stops, Financial Factors and Economic Collapse in Latin America: Learning from Argentina and Chile," NBER Working Paper 11153. 
Calvo, G. A., A. Izquierdo, and E. Talvi (2006): "Phoenix Miracles in Emerging Markets: Recovering without Credit from Systemic Financial Crises," NBER Working Paper 12101.

Cameron, C. A., and P. K. Trivedi (2005): Microeconometrics: Methods and Applications. Cambridge University Press.

Chinn, M. D., And H. Ito (forthcoming): "What Matters for Financial Development? Capital Controls, Institutions, and Interactions," Journal of Development Economics.

Desai, M. A., C. F. Foley, and K. J. Forbes (2004): "Financial Constraints and Growth: Multinational and Local Firm Responses to Currency Crises," NBER Working Paper No. W10545.

DeYoung, R., D. Glennon, and P. Nigro (2006): "Borrower-Lender Distance, Credit Scoring, and the Performance of Small Business Loans," FDIC Center for Financial Research WP 2006-04.

Dooley, M. P., and S. Verma (2003): "Rescue Packages and Output Losses Following Crises," in Managing currency crises in emerging markets, pp. 125-41. NBER Conference Report series. Chicago and London: University of Chicago Press.

Drudi, F., And R. Giordano (2000): "Default risk and optimal debt management," Journal of Banking and Finance, 24, 861-891.

Eichengreen, B., G. Hale, And A. Mody (2001): "Flight to Quality: Investor Risk Tolerance and the Spread of Emerging Market Crises," in International Financial Contagion, ed. by S.Classens, and K.Forbes. Kluwer.

Eichengreen, B., and R. Hausmann (1999): "Exchange Rates and Financial Fragility," NBER Working Papers: 7418.

Eichengreen, B., R. Hausmann, and U. Panizza (2002): "Original Sin: The Pain, the Mystery, and the Road to Redemption," in Currency and Maturity Matchmaking:Redeeming Debt from Original Sin. Inter-American Development Bank.

Eichengreen, B., And P. H. Lindert (1989): The International Debt Crisis in Historical Perspectivechap. 1 - Overview. The MIT Press, Cambridge, Massachusetts.

Eichengreen, B., And A. Mody (2000a): "Lending Booms, Reserves and Sustainability of ShortTerm Debt: Inferences from the Pricing of Syndicated Bank Loans," Journal of Development Economics, 63(1), 5-44.

(2000b): "What Explains Changing Spreads on Emerging-Market Debt? Fundamentals or Market Sentiment?," in The Economics of International Capital Flows, ed. by S. Edwards. University of Chicago Press.

Feenstra, R., J. Romalis, and P. Schott (2002): "U.S. Imports, Exports and Tariff Data, 1989 to 2001," NBER WP 9387. 
Frankel, J. A., And E. A. Cavallo (2004): "Does Openness to Trade Make Countries More Vulnerable to Sudden Stops, or Less? Using Gravity to Establish Causality," NBER Working Paper 10957.

Gelos, R. G., R. Sahay, and G. Sandleris (2004): "Sovereign Borrowing by Developing Countries: What determines market access?," IMF Working Paper.

Glick, R., And M. Hutchison (2005): "Capital Controls and Exchange Rate Instability in Developing Countries," Journal of International Money and Finance, 24(3), 387-412.

Goldberg, L., And C. Tille (2005): "Vehicle Currency Use in Interantional Trade," FRB New York Staff Report 200, Federal Reserve Bank of New York.

Hale, G. (2007): "Bonds or Loans? The Effect of Macroeconomic Fundamentals," Economic Journal.

Helpman, E. (2006): "Trade, FDI, and the Organization of Firms," NBER WP 12091.

Hutchison, M., And I. Noy (2005): "How Bad are Twins? Output Costs of Currency and Banking Crises," Journal of Money, Credit and Banking, 37(4), 725-752.

Kallberg, L. G., C. H. Liu, and P. Pasquariello (2002): "An Examination of the Asian Crisis Part I: Regime Shifts in Currency and Equity Markets," mimeo, Stern School of Business.

Kaminsky, G., S. Lizondo, and C. M. Reinhart (1998): "Leading Indicators of Currency Crises," IMF Staff Papers, 45, 1-48.

Lane, P., and G. M. Milesi-Ferretti (1999): "The External Wealth of Nations: Measures of Foreign Assets and Liabilities for Industrial and Developing Countries," IMF Working Paper No. $99 / 115$.

Martinez, J. V., and G. Sandleris (2004): "Is it Punishment? Sovereign Defaults and the Declines in Trade," mimeo, http://www.columbia.edu/ gms118/research.htm.

Mason, R. (1998): “An Options-based Model of Equilibrium Credit Rationing," Journal of Corporate Finance, 4, 71-85.

Mendoza, E. (2006): "Endogenous Sudden Stops in a Business Cycle Model with Collateral Constraints: A Fisherian Deflation of Tobin's Q," NBER WP 12564.

Mody, A., M. P. TAYlor, And J. Y. Kim (2001): "Modelling Fundamentals for Forecasting Capital Flows to Emerging Markets," International Journal of Finance and Economics, 6, 201216.

Ozler, S. (1993): "Have Commercial Banks Ignored History?," American Economic Review, 83(3), $608-20$. 
Pasquariello, P. (2005): "Are Financial Crises Indeed "Crises"? Evidence from the Emerging ADR Market," mimeo, Ross School of Business at the University of Michigan.

Perri, F., And A. Neumeyer (2005): "Business Cycles in Emerging Economies: the Role of Interest Rates," Journal of Monetary Economics, 52(2), 345-380.

Rajan, R., And L. Zingales (1998): "Financial Dependence and Growth," American Economic Review, 88(3).

Reinhart, C. M., and K. S. Rogoff (2004): "Serial Default and the "Paradox" of Rich to Poor Capital Flows," American Economic Review, 94, 51-74.

Reinhart, C. M., K. S. Rogoff, and M. A. Savastano (2003): "Debt Intolerance," Brookings Papers on Economic Activity, 1, 1-62.

Rose, A. (2005): "One Reason Countries Pay Their Debts: Renegotiation and International Trade," Journal of Development Economics, 77, 189-206.

SAndleRIS, G. (2005): "Sovereign Default: Information, Investment and Credit," mimeo, Columbia Universtity.

Schneider, M., and A. Tornell (2004): "Balance Sheet Effects, Bailout Guarantees and Financial Crises," The Review of Economic Studies, 71(3).

Stiglitz, J. E., And A. Weiss (1981): "Credit Rationing in Markets with Imperfect Information," The American Economics Review, 71(3), 393-410.

Sturzenegger, F., and J. Zettelmeyer (2005): "Haircuts: Estimating Investor Losses in Sovereign Debt Restructurings, 1998-2005," IMF Working Paper WP/05/137.

(2006): Debt Defaults and Lessons from a Decade of Crises. MIT Press.

Tomz, M., And M. L. Wright (2005): "Sovereign Debt, Defaults and Bailouts," Paper presented at the NBER IFM SI 2005.

Uribe, M., And Z. V. Yue (2006): "Country Spreads and Emerging Countries: Who Drives Whom?," Journal of International Economics, 69(1), 6-36.

Yue, V. (2005): "Sovereign Default and Debt Renegotiation," mimeo, New York University. 


\section{Appendix: Data formats and sources}

[Insert Tables 9 and 10 about here]

\section{Indexes}

The indexes were constructed using the full sample with weights zero assigned to missing variables. Here we present the linear combinations of the variables that are our indexes. All the variables enter as their percentage deviations from the country-specific means in a standardized form, which renders them unit-free and comparable.

$$
\begin{aligned}
& \text { Index } 1.1=(0.63 * T O T+0.024 * \dot{C A}-0.071 * R \dot{E} R-0.68 * E P I+0.35 * V O L T) * T O, \\
& \text { Index } 1.2=(0.24 * T O T+0.81 * \dot{C} A+0.49 * R \dot{E} R+0.0010 * E P I-0.20 * V O L T) * T O,
\end{aligned}
$$
where

$\begin{array}{lll}\text { TOT } & \text { Terms of Trade } & \mathrm{Up}=\text { Improvement } \\ C A & \text { Change in CA } & \mathrm{Up}=\text { Improvement } \\ R \dot{E} R & \text { Change in Real Exchange Rate } & \mathrm{Up}=\text { Appreciation } \\ E P I & \text { Export Price Index } & \mathrm{Up}=\text { Increase } \\ V O L T & \text { Trade Volatility } & \mathrm{Up}=\text { Increase } \\ \text { TO } & \text { Trade Openness }(\mathrm{EX}+\mathrm{IM}) / \mathrm{GDP} & \mathrm{Up}=\text { Increase }\end{array}$

$$
\begin{aligned}
\text { Index } 2.1= & 0.033 * S C R+0.053 * D S / E X-0.67 * I / Y+0.19 * R I R \\
& -0.16 * L R / D R-0.045 * I N F L+0.70 * D C / Y+0.0015 * \dot{S} I \\
\text { Index } 2.2= & 0.57 * S C R-0.12 * D S / E X+0.05 * I / Y+0.31 * R I R \\
& -0.39 * L R / D R+0.63 * I N F L-0.010 * D C / Y-0.0076 * \dot{S} I \\
\text { Index } 2.3= & 0.25 * S C R+0.81 * D S / E X+0.21 * I / Y+0.37 * R I R \\
& -0.041 * L R / D R-0.29 * I N F L-0.0007 * D C / Y+0.039 * \dot{S} I
\end{aligned}
$$

where

$\begin{array}{lll}S C R & \text { Sovereign Credit Risk } & \mathrm{Up}=\text { Lower risk } \\ D S / E X & \text { Debt Service/Exports } & \mathrm{Up}=\text { Increase } \\ I / Y & \text { Investment/GDP } & \mathrm{Up}=\text { Increase } \\ R I R & \text { Real Interest Rate } & \mathrm{Up}=\text { Increase } \\ L R / D R & \text { Lending Rate/Deposit Rate } & \mathrm{Up}=\text { Increase } \\ I N F L & \text { Inflation Rate } & \mathrm{Up}=\text { Increase } \\ D C / Y & \text { Domestic Credit/GDP } & \mathrm{Up}=\text { Increase } \\ \dot{S} I & \text { Change in Stock Market Index } & \mathrm{Up}=\text { Increase }\end{array}$


Index $3.1=0.60 * O P E N+0.55 * B A+0.58 * S M$

where

OPEN Financial Account Openness $\quad \mathrm{Up}=$ More open

$B A \quad$ Commercial Bank Assets/GDP Up = Increase

$S M \quad$ Stock Market Capitalization/GDP Up $=$ Increase

$$
\begin{aligned}
& \text { Index } 4.1=0.40 * F D / Y+0.61 * \hat{Y}-0.50 * \hat{P Y}+0.46 * U, \\
& \text { Index } 4.2=0.59 * F D / Y-0.28 * \hat{Y}+0.57 * \hat{P Y}+0.49 * U,
\end{aligned}
$$

where
$F D / Y \quad$ Foreign Debt/GDP
$\mathrm{UP}=$ Increase
$\hat{Y} \quad$ Growth Rate of Real GDP
$\mathrm{Up}=$ Increase
$\hat{P Y}$
Growth Rate of GDP in US Dollars
$\mathrm{Up}=$ Increase
$U$
Unemployment Rate
$\mathrm{Up}=$ Increase

Index 5.1 = ICRG Political Stability Index.

Finally,

$$
\begin{gathered}
\text { Index } 6.1=-0.60 * C O+0.34 * C I+0.39 * T R+0.59 * H Y+0.16 * U \hat{S S I}, \\
\text { Index } 6.2=0.37 * C O+0.62 * C I+0.55 * T R-0.38 * H Y+0.18 * U \hat{S S I},
\end{gathered}
$$

where

$\begin{array}{lll}C O & \text { Gross Capital Outflows from OECD } & \mathrm{Up}=\text { Increase } \\ C I & \text { Investor Confidence Index } & \mathrm{Up}=\text { More confidence } \\ T R & \text { U.S. Treasury Rate } & \mathrm{Up}=\text { Increase } \\ H Y & \text { ML High Yield Spread } & \mathrm{Up}=\text { Increase } \\ U \hat{S S I} & \text { Growth Rate of U.S. Stock Market Index } & \mathrm{Up}=\text { Increase }\end{array}$


Figure 1: Composition of new foreign borrowing by private domestically owned firms in the sample

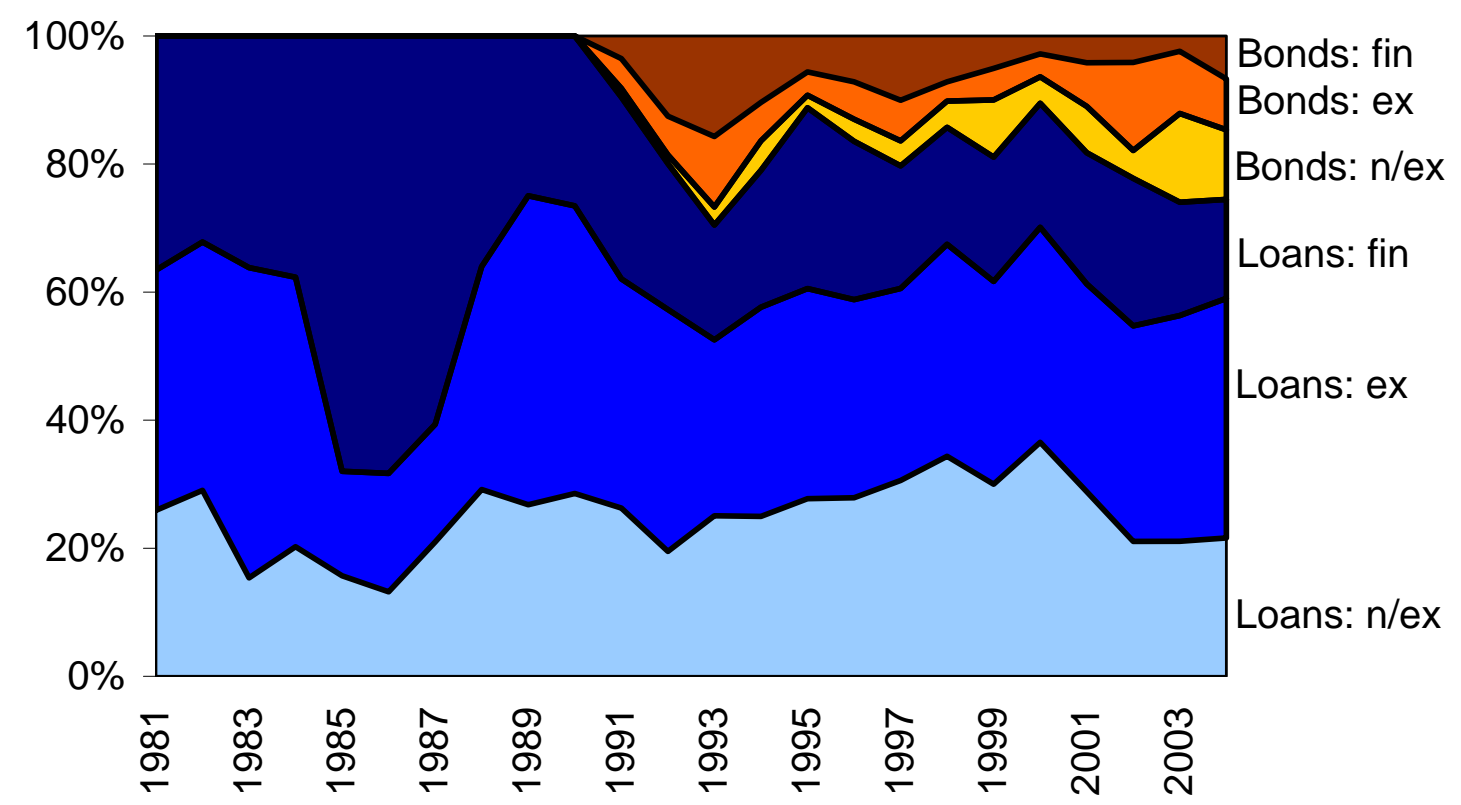

Note: fin $=$ financial sector, $\mathrm{ex}=$ non-financial exporting sector, $\mathrm{n} / \mathrm{ex}=$ non-financial non-exporting sector 
Figure 2: Percentage deviation of the amount borrowed from its country mean

\section{All firms}

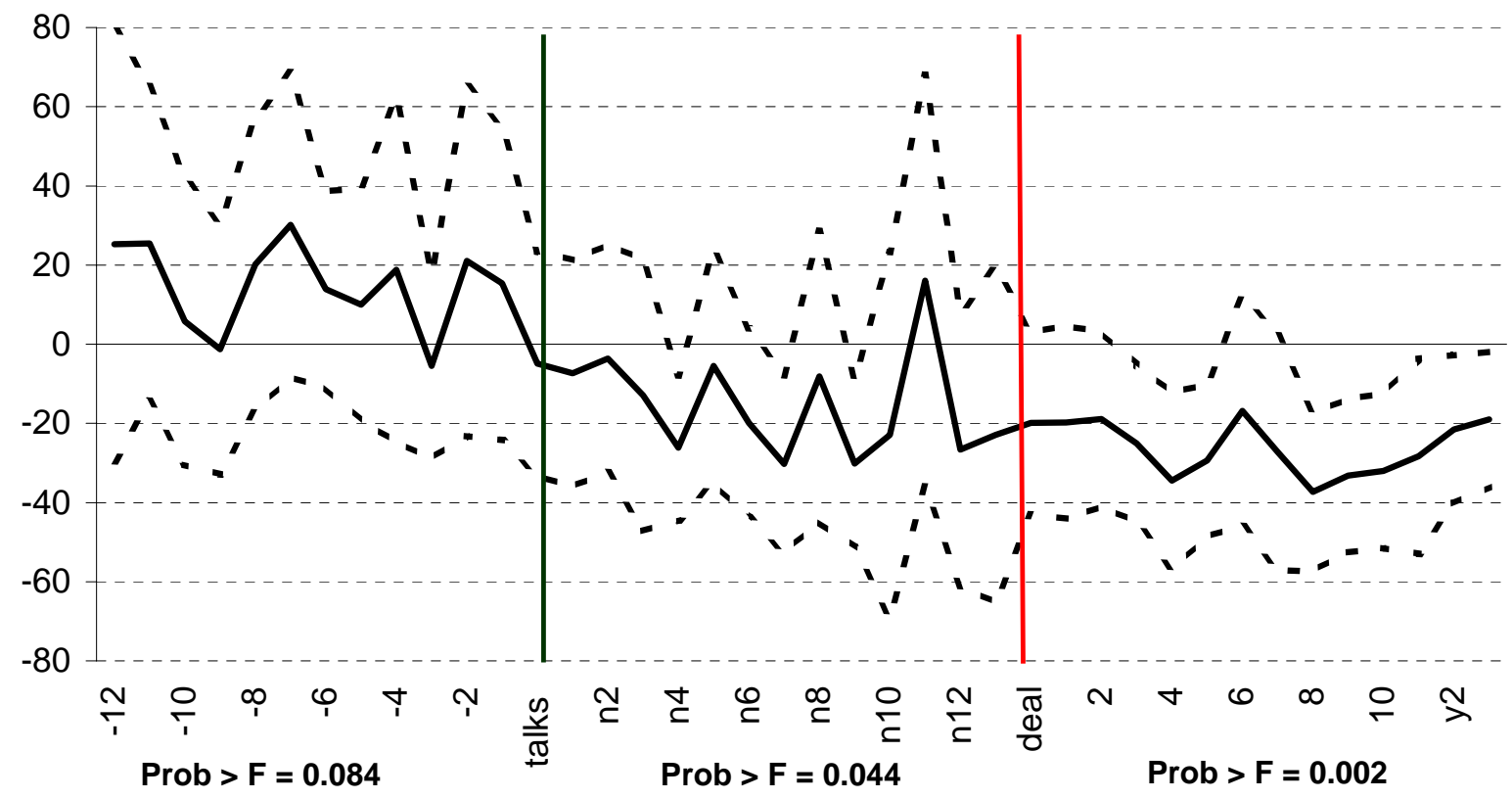

Note: Each point on the solid line represents a $\beta$-coefficient on the appropriate lead or lag in the regression where the dependent variable is the percentage deviations of the amount borrowed. Dashed lines represent a $95 \%$ confidence interval fr each $\beta$-coefficient. "talks" indicates the month during which debt renegotiations started, "deal" indicates the month in which the debt restructuring agreement was reached. "Prob $>$ F" indicates the P-values for the test of the hypothesis that the sum of the coefficients in the relevant range is different from zero. 
Figure 3: Percentage deviation of the amount borrowed from its country mean: by sector

\section{Financials}

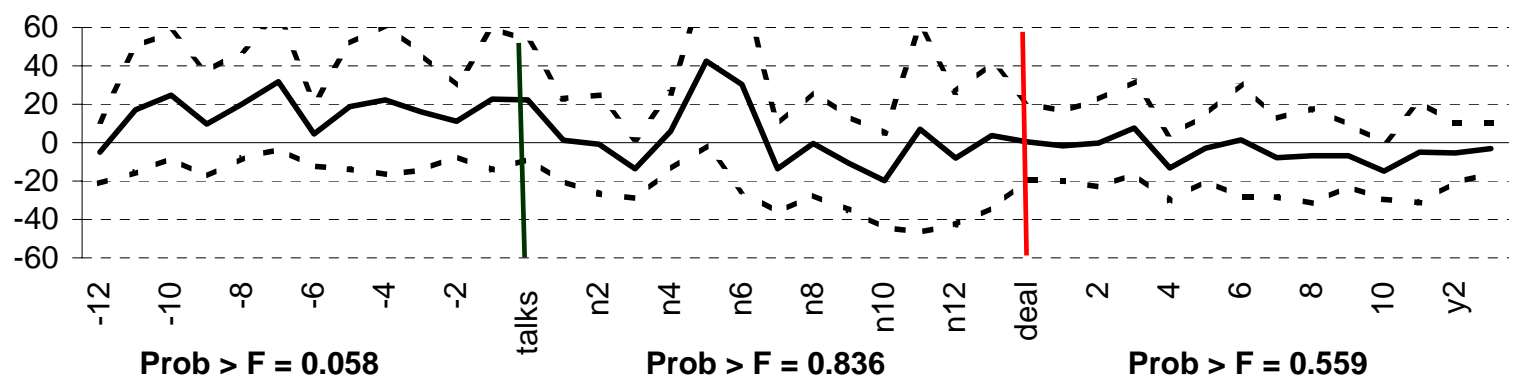

Non-financials

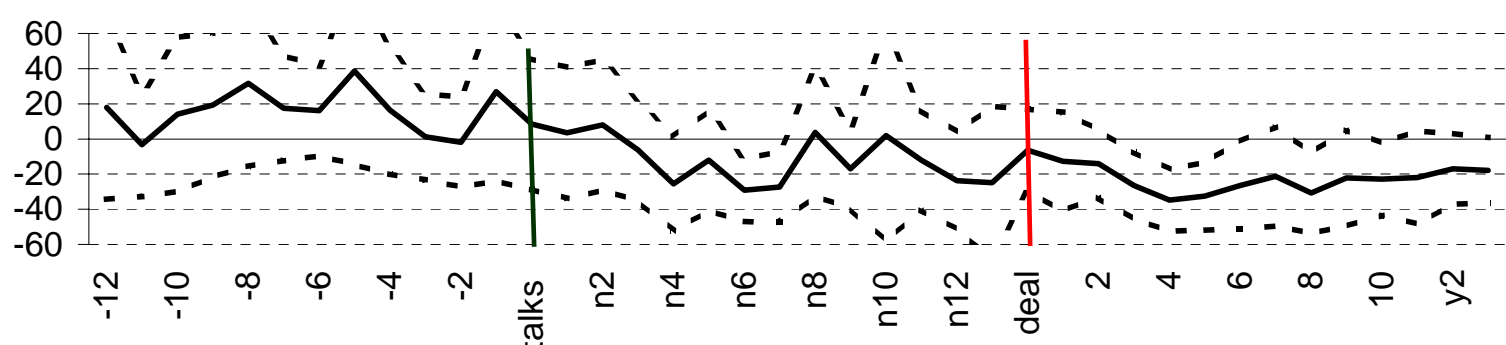

Prob $>\mathrm{F}=0.114$

Prob $>\mathrm{F}=0.113$

Prob > F $=0.011$

\section{Exporters}

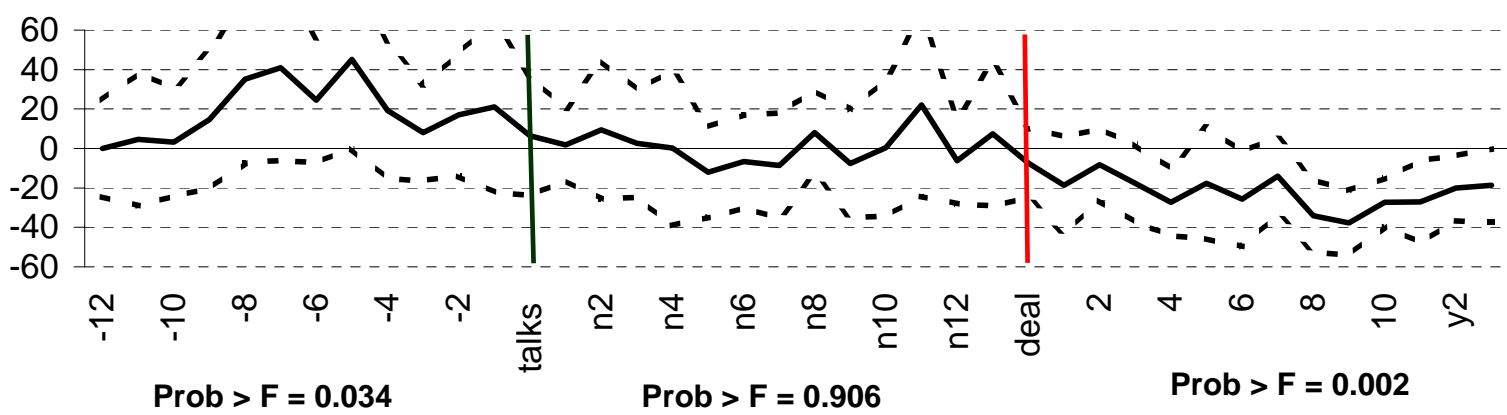

Non-exporters

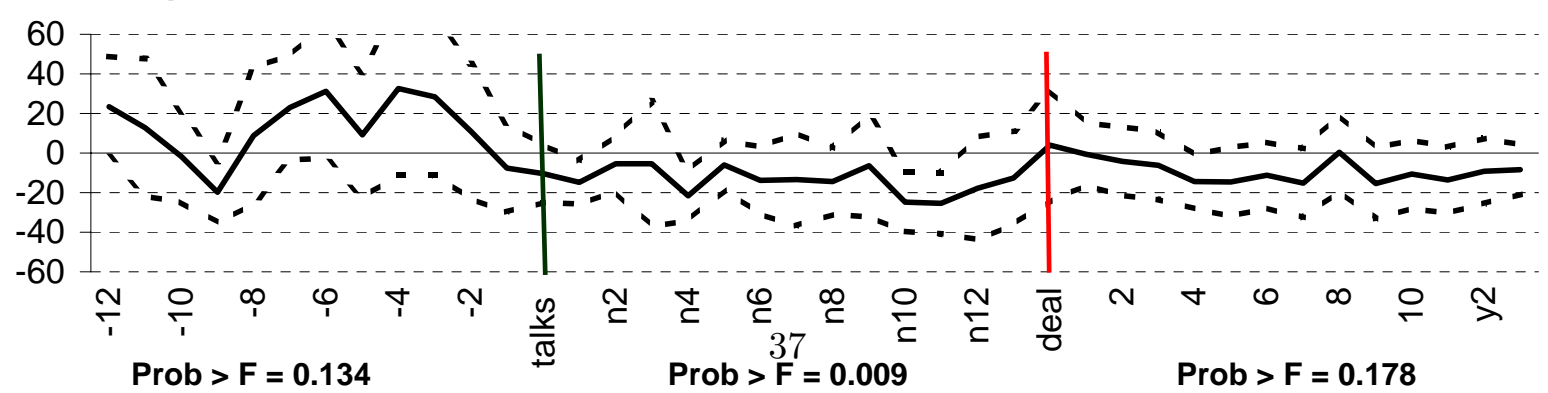

Note: See notes for Figure 2. 
Table 1: Number of renegotiations and restructuring episodes by country

\begin{tabular}{|c|c|c|c|c|c|c|}
\hline Country & $\begin{array}{c}\text { Years in sample } \\
(1)\end{array}$ & $\begin{array}{c}\text { Negotiations }^{a} \\
(2) \\
\end{array}$ & $\begin{array}{l}\text { All } \\
\text { resched. }^{a} \\
(3)\end{array}$ & $\begin{array}{c}\text { Swaps and } \\
\text { buybacks }^{a} \\
(4)\end{array}$ & $\begin{array}{c}\text { Commercial } \\
\text { resched. }{ }^{a} \\
(5)\end{array}$ & $\begin{array}{c}\text { Include } \\
\text { New money }^{a} \\
(6)\end{array}$ \\
\hline Algeria & 1984-2001 & 2 & 4 & 0 & 2 & 0 \\
\hline Argentina & $1985-2003$ & 5 & 19 & 10 & 14 & 4 \\
\hline Bahrain & 1984-2001 & 0 & 0 & 0 & 0 & 0 \\
\hline Brazil & $1990-2003$ & 4 & 17 & 7 & 13 & 3 \\
\hline Chile & 1984-2004 & 4 & 10 & 1 & 8 & 4 \\
\hline China & 1994-2003 & 0 & 0 & 0 & 0 & 0 \\
\hline Colombia & 1984-2004 & 4 & 4 & 4 & 4 & 2 \\
\hline Croatia & 1999-2004 & 1 & 1 & 0 & 0 & 0 \\
\hline Egypt & 1984-2001 & 2 & 2 & 0 & 0 & 0 \\
\hline Ghana & $1984-2001$ & 0 & 2 & 0 & 0 & 0 \\
\hline Hong Kong & $1990-2003$ & 0 & 0 & 0 & 0 & 0 \\
\hline Hungary & 1984-2004 & 0 & 0 & 0 & 0 & 0 \\
\hline India & 1988-2001 & 0 & 0 & 0 & 0 & 0 \\
\hline Indonesia & $1984-2003$ & 1 & 3 & 0 & 1 & 0 \\
\hline Korea & $1985-2003$ & 1 & 1 & 0 & 0 & 0 \\
\hline Malaysia & 1984-2004 & 0 & 0 & 0 & 0 & 0 \\
\hline Mexico & 1984-2002 & 3 & 26 & 15 & 23 & 4 \\
\hline Pakistan & 1984-2002 & 3 & 4 & 0 & 0 & 0 \\
\hline Peru & $1988-2003$ & 4 & 6 & 0 & 2 & 1 \\
\hline Philippines & 1984-2004 & 6 & 11 & 4 & 6 & 3 \\
\hline Poland & 1990-2004 & 8 & 15 & 1 & 9 & 0 \\
\hline Romania & 1991-2002 & 3 & 6 & 0 & 4 & 0 \\
\hline Russia & 1994-2002 & 3 & 10 & 0 & 0 & 0 \\
\hline Saudi Arabia & 1984-2002 & 0 & 0 & 0 & 0 & 0 \\
\hline Singapore & 1984-2002 & 0 & 0 & 0 & 0 & 0 \\
\hline Slovakia & 1993-2004 & 0 & 0 & 0 & 0 & 0 \\
\hline South Africa & 1984-2004 & 2 & 5 & 0 & 5 & 0 \\
\hline Thailand & 1984-2003 & 0 & 0 & 0 & 0 & 0 \\
\hline Turkey & $1984-2003$ & 1 & 2 & 1 & 2 & 0 \\
\hline Venezuela & 1984-2002 & 5 & 7 & 2 & 7 & 2 \\
\hline Total & & 60 & 155 & 45 & 100 & 23 \\
\hline
\end{tabular}

${ }^{a}$ Number of renegotiations and restructuring in 1980-2002. 
Table 2: New borrowing by emerging markets' private domestically owned firms in the sample

\begin{tabular}{|c|c|c|c|c|c|c|c|c|c|c|c|}
\hline \multirow[t]{3}{*}{ Year } & \multirow{3}{*}{$\begin{array}{l}\text { Total } \\
(1) \\
\end{array}$} & \multicolumn{5}{|c|}{$\underline{\text { Loans }}$} & \multicolumn{5}{|c|}{ Bonds } \\
\hline & & \multirow{2}{*}{$\begin{array}{c}\text { Total } \\
(2) \\
\end{array}$} & \multirow{2}{*}{$\begin{array}{c}\text { Fin. } \\
(3) \\
\end{array}$} & \multicolumn{3}{|c|}{ Nonfinancial } & \multirow{2}{*}{$\begin{array}{c}\text { Total } \\
(7) \\
\end{array}$} & \multirow{2}{*}{$\begin{array}{l}\text { Fin. } \\
(8)\end{array}$} & \multicolumn{3}{|c|}{ Nonfinancial } \\
\hline & & & & $\begin{array}{c}\text { Total } \\
(4)\end{array}$ & $\begin{array}{c}\text { Exp. } \\
(5)\end{array}$ & $\begin{array}{c}\text { Not exp. } \\
\quad(6)\end{array}$ & & & $\begin{array}{c}\text { Total } \\
(9)\end{array}$ & $\begin{array}{l}\text { Exp. } \\
(10)\end{array}$ & $\begin{array}{c}\text { Non-exp. } \\
\quad(11)\end{array}$ \\
\hline 1981 & 29.2 & 29.2 & 10.7 & 18.5 & 11.0 & 7.6 & & & & & \\
\hline 1982 & 26.6 & 26.6 & 8.6 & 18.1 & 10.3 & 7.7 & & & & & \\
\hline 1983 & 16.1 & 16.1 & 5.8 & 10.3 & 7.8 & 2.5 & & & & & \\
\hline 1984 & 19.6 & 19.6 & 7.4 & 12.2 & 8.3 & 4.0 & & & & & \\
\hline 1985 & 19.4 & 19.4 & 13.2 & 6.2 & 3.2 & 3.1 & & & & & \\
\hline 1986 & 17.2 & 17.2 & 11.7 & 5.4 & 3.2 & 2.3 & & & & & \\
\hline 1987 & 14.4 & 14.4 & 8.7 & 5.7 & 2.6 & 3.0 & & & & & \\
\hline 1988 & 13.3 & 13.3 & 4.8 & 8.5 & 4.6 & 3.9 & & & & & \\
\hline 1989 & 22.6 & 22.6 & 5.6 & 16.9 & 10.9 & 6.0 & & & & & \\
\hline 1990 & 29.4 & 29.4 & 7.8 & 21.6 & 13.2 & 8.4 & & & & & \\
\hline 1991 & 44.0 & 39.8 & 12.5 & 27.3 & 15.7 & 11.6 & 4.2 & 1.6 & 2.6 & 2.0 & 0.6 \\
\hline 1992 & 51.7 & 41.4 & 11.8 & 29.6 & 19.5 & 10.1 & 10.3 & 6.5 & 3.8 & 3.1 & 0.7 \\
\hline 1993 & 64.8 & 45.7 & 11.6 & 34.1 & 17.8 & 16.3 & 19.1 & 10.2 & 9.0 & 7.1 & 1.8 \\
\hline 1994 & 83.8 & 66.2 & 17.9 & 48.3 & 27.4 & 20.9 & 17.6 & 8.7 & 8.9 & 5.0 & 3.9 \\
\hline 1995 & 111.2 & 98.7 & 31.4 & 67.3 & 36.5 & 30.8 & 12.5 & 6.2 & 6.2 & 4.0 & 2.2 \\
\hline 1996 & 147.3 & 123.1 & 36.4 & 86.6 & 45.6 & 41.1 & 24.2 & 10.5 & 13.7 & 8.6 & 5.1 \\
\hline 1997 & 209.9 & 167.3 & 40.2 & 127.1 & 62.9 & 64.2 & 42.6 & 21.1 & 21.5 & 13.3 & 8.2 \\
\hline 1998 & 105.7 & 90.6 & 19.3 & 71.3 & 35.0 & 36.3 & 15.1 & 7.6 & 7.5 & 3.2 & 4.3 \\
\hline 1999 & 81.5 & 66.1 & 15.8 & 50.2 & 25.8 & 24.4 & 15.4 & 4.1 & 11.3 & 4.0 & 7.3 \\
\hline 2000 & 140.1 & 125.4 & 27.1 & 98.2 & 47.0 & 51.2 & 14.7 & 3.9 & 10.8 & 5.0 & 5.8 \\
\hline 2001 & 97.3 & 79.5 & 19.9 & 59.6 & 31.6 & 28.0 & 17.7 & 4.1 & 13.7 & 6.6 & 7.0 \\
\hline 2002 & 81.4 & 63.3 & 18.7 & 44.5 & 27.4 & 17.1 & 18.1 & 3.4 & 14.7 & 11.2 & 3.5 \\
\hline 2003 & 102.9 & 76.2 & 18.2 & 58.0 & 36.3 & 21.7 & 26.7 & 2.5 & 24.3 & 10.0 & 14.3 \\
\hline $2004^{*}$ & 64.7 & 48.2 & 10.0 & 38.2 & 24.2 & 14.0 & 16.5 & 4.3 & 12.2 & 5.1 & 7.0 \\
\hline Total & 1594.1 & 1339.3 & 375.4 & 963.9 & 527.8 & 436.1 & 254.8 & 94.5 & 160.2 & 88.5 & 71.7 \\
\hline$\%$ of total & & 84.0 & 23.5 & 60.5 & 33.1 & 27.4 & 16.0 & 5.9 & 10.1 & 5.6 & 4.5 \\
\hline
\end{tabular}

*Through August 2004

Measured in bln. USD. Sum over all the countries listed in Table 1.

Numbers for loans represent the size of facilities, not actual amounts drawn. 
Table 3: Summary of indexes

\begin{tabular}{|c|c|c|c|}
\hline Concept & Variables & Notes & Indexes \\
\hline $\begin{array}{l}\text { International } \\
\text { competitiveness }\end{array}$ & $\begin{array}{c}\text { Terms of trade } \\
\text { Change in CA } \\
\text { Change in real exchange rate } \\
\text { Export commodity prices } \\
\text { Volatility of export revenues } \\
\end{array}$ & $\begin{array}{l}\text { Scaled by trade } \\
\quad \text { openness } \\
\text { Lagged } 1 \text { month }\end{array}$ & $\begin{array}{l}1.1 \\
1.2\end{array}$ \\
\hline $\begin{array}{l}\text { Investment climate and } \\
\text { monetary stability }\end{array}$ & $\begin{array}{c}\text { Sovereign credit risk } \\
\text { Debt service/Exports } \\
\text { Investment/GDP } \\
\text { Real interest rate } \\
\text { Lending rate/Deposit rate } \\
\text { Inflation rate } \\
\text { Domestic credit/GDP } \\
\text { Change in stock market index }\end{array}$ & Lagged 1 month & $\begin{array}{l}2.1 \\
2.2 \\
2.3\end{array}$ \\
\hline Financial development & $\begin{array}{c}\text { Financial account openness } \\
\text { Comm.bank assets/GDP } \\
\text { Stock market cap./GDP }\end{array}$ & Lagged 1 month & 3.1 \\
\hline $\begin{array}{l}\text { Long-run macroeconomic } \\
\text { prospects }\end{array}$ & $\begin{array}{c}\text { Foreign debt/GDP } \\
\text { Growth rate of real GDP } \\
\text { Growth rate of GDP in USD } \\
\text { Unemployment rate }\end{array}$ & Lagged 1 month & $\begin{array}{l}4.1 \\
4.2\end{array}$ \\
\hline Political stability & ICRG political stability index & Lagged 1 month & 5.1 \\
\hline Global supply of capital & $\begin{array}{c}\text { Gross capital outflows from OECD } \\
\text { Investor confidence index } \\
\text { US Treasury rate } \\
\text { ML High Yield Spread } \\
\text { Growth rate of US stock mkt. index }\end{array}$ & Not lagged & $\begin{array}{l}6.1 \\
6.2\end{array}$ \\
\hline
\end{tabular}


Table 4: Sample industries in exporting and non-exporting categories

\begin{tabular}{ll}
\hline \hline \multicolumn{1}{c}{ Exporting } & \multicolumn{1}{c}{ Non-exporting } \\
\hline Chemicals & Food and drinks \\
International airlines and shipping & TV and radio services \\
Oil and gas industry & Communication services \\
Motor vehicles & Construction and related \\
Minerals and timber & Utilities \\
Electric services & Retail \\
Manufactured goods & Restaurants, hotels, leisure \\
Agricultural products & Electric services \\
Food, drinks, tobacco & Transportation and storage \\
Steel and aluminum & Domestic airlines and shipping \\
\hline \hline
\end{tabular}

Note: some industries appear in both columns due to different export structure of different countries. 
Table 5: Effects of debt renegotiations and restructuring on total amount borrowed

\begin{tabular}{|c|c|c|c|c|c|c|}
\hline & $(1)$ & $(2)$ & $(3)$ & $(4)$ & $(5)$ & $(6)$ \\
\hline Month renegotiations began & & $\begin{array}{l}-12.01 \\
(10.04)\end{array}$ & $\begin{array}{c}-7.84 \\
(13.85)\end{array}$ & $\begin{array}{c}-8.49 \\
(17.97)\end{array}$ & $\begin{array}{c}-7.33 \\
(14.15)\end{array}$ & $\begin{array}{c}-12.5 \\
(14.43)\end{array}$ \\
\hline Renegotiations continue & & $\begin{array}{c}-30.13^{* * *} \\
(7.25)\end{array}$ & $\begin{array}{c}-18.80^{* *} \\
(9.38)\end{array}$ & $\begin{array}{c}-18.39^{* * *} \\
(6.44)\end{array}$ & $\begin{array}{c}-14.74^{*} \\
(8.81)\end{array}$ & $\begin{array}{c}-20.14^{* *} \\
(8.92)\end{array}$ \\
\hline Month of debt restructuring & & $\begin{array}{c}-44.37^{* * *} \\
(11.65)\end{array}$ & $\begin{array}{c}-23.36^{* *} \\
(11.82)\end{array}$ & $\begin{array}{c}-23.80^{* *} \\
(10.58)\end{array}$ & $\begin{array}{c}-22.84^{* *} \\
(11.17)\end{array}$ & $\begin{array}{c}-27.05^{* *} \\
(12.39)\end{array}$ \\
\hline Year 1 since debt restructuring & & $\begin{array}{c}-43.70^{* * *} \\
(8.04)\end{array}$ & $\begin{array}{c}-29.67^{* * *} \\
(9.30)\end{array}$ & $\begin{array}{c}-29.49^{* * *} \\
(6.00)\end{array}$ & $\begin{array}{c}-26.94^{* * *} \\
(9.21)\end{array}$ & $\begin{array}{c}-32.50^{* * *} \\
(10.45)\end{array}$ \\
\hline Year 2 since debt restructuring & & $\begin{array}{c}-34.26^{* * *} \\
(8.86)\end{array}$ & $\begin{array}{c}-23.99^{* *} \\
(9.90)\end{array}$ & $\begin{array}{c}-23.72^{* * *} \\
(6.31)\end{array}$ & $\begin{array}{c}-20.38^{* *} \\
(9.30)\end{array}$ & $\begin{array}{c}-23.62^{* *} \\
(9.95)\end{array}$ \\
\hline Year 3 since debt restructuring & & $\begin{array}{c}-17.99^{* *} \\
(8.83) \\
\end{array}$ & $\begin{array}{c}-20.96^{* *} \\
(9.28) \\
\end{array}$ & $\begin{array}{c}-21.31^{* * *} \\
(7.07) \\
\end{array}$ & $\begin{array}{c}-18.26^{* *} \\
(7.85) \\
\end{array}$ & $\begin{array}{c}-20.69^{* *} \\
(8.18) \\
\end{array}$ \\
\hline Index 1.1 & -5.07 & & -5.41 & $-5.52^{* * *}$ & -4.20 & -3.61 \\
\hline Index 1.2 & 0.73 & & 0.81 & 0.74 & 0.92 & 0.95 \\
\hline Index 2.1 & 3.46 & & 2.04 & 2.08 & 1.87 & 0.56 \\
\hline Index 2.2 & -1.34 & & -2.20 & -2.13 & -2.38 & -2.63 \\
\hline Index 2.3 & -1.94 & & -2.36 & -2.32 & $-3.61^{* *}$ & $-4.18^{* *}$ \\
\hline Index 3.1 & $6.43^{* *}$ & & $6.29^{* *}$ & $5.69^{* * *}$ & $5.76^{* *}$ & $5.50 * *$ \\
\hline Index 4.1 & $3.07^{* *}$ & & $2.98^{* *}$ & $3.03^{* * *}$ & $2.68^{* *}$ & $2.65^{* *}$ \\
\hline Index 4.2 & -0.37 & & -0.41 & -0.33 & -0.24 & 0.04 \\
\hline Index 5.1 & $1.03^{* * *}$ & & $0.93^{* * *}$ & $0.97^{* * *}$ & $0.84^{* * *}$ & $0.79^{* * *}$ \\
\hline Index 6.1 & $-17.42^{* * *}$ & & $-16.72^{* * *}$ & $-15.96 * * *$ & $-15.97 * * *$ & $-15.80 * * *$ \\
\hline Index 6.2 & $18.78^{* * *}$ & & $18.57^{* * *}$ & $17.86^{* * *}$ & $16.57^{* * *}$ & $16.79^{* * *}$ \\
\hline Real exchange rate & $-13.17^{* * *}$ & & $-11.42^{* * *}$ & $-11.14^{* * *}$ & $-9.73^{* * *}$ & $-9.27 * * *$ \\
\hline Banking crisis indicator & $-25.07 * * *$ & & $-26.05^{* * *}$ & $-25.55^{* * *}$ & $-25.92^{* * *}$ & $-25.84^{* * *}$ \\
\hline IMF agreement indicator & $-19.20^{* * *}$ & & $-12.50^{*}$ & $-12.48^{* * *}$ & $-11.85^{*}$ & $-10.52^{*}$ \\
\hline Lagged dependent variable & & & & & $0.083^{* * *}$ & *country \\
\hline Constant & $-74.88^{* * *}$ & $-57.28 * * *$ & $-76.88^{* * *}$ & $49.88^{* * *}$ & $-72.34^{* * *}$ & $-74.65 * * *$ \\
\hline Observations & 5515 & 9186 & 5515 & 5485 & 5244 & 5244 \\
\hline Adjusted $R^{2}$ & 0.20 & 0.18 & 0.20 & & 0.20 & 0.21 \\
\hline$\rho(\mathrm{AR})$ & & & & 0.08 & & \\
\hline
\end{tabular}

Dependent variable: total amount borrowed in percentage deviations from the mean.

Country and year fixed effects are included in all regressions.

Robust standard errors clustered on country are in parentheses.

* significant at $10 \%$; $* *$ significant at $5 \%$; *** sisnificant at $1 \%$. 
Table 6: Effects of debt renegotiations and restructuring by type of borrower

\begin{tabular}{|c|c|c|c|c|}
\hline & $\begin{array}{c}\text { Financial } \\
(1) \\
\end{array}$ & $\begin{array}{l}\text { All } \\
(2) \\
\end{array}$ & $\begin{array}{c}\text { Nonfinancial } \\
\text { Exporting } \\
(3)\end{array}$ & $\begin{array}{c}\text { Not exporting } \\
(4)\end{array}$ \\
\hline Month renegotiations began & $\begin{array}{c}20.15 \\
(15.82)\end{array}$ & $\begin{array}{c}4.84 \\
(18.46)\end{array}$ & $\begin{array}{c}1.62 \\
(14.43)\end{array}$ & $\begin{array}{c}-13.62^{* *} \\
(6.07)\end{array}$ \\
\hline Renegotiations continue & $\begin{array}{c}-0.47 \\
(11.14)\end{array}$ & $\begin{array}{c}-16.56^{*} \\
(9.22)\end{array}$ & $\begin{array}{l}-3.64 \\
(6.98)\end{array}$ & $\begin{array}{c}-12.60^{* *} \\
(5.94)\end{array}$ \\
\hline Month of debt restructuring & $\begin{array}{c}-0.78 \\
(10.70)\end{array}$ & $\begin{array}{c}-8.86 \\
(12.36)\end{array}$ & $\begin{array}{c}-9.67 \\
(10.16)\end{array}$ & $\begin{array}{c}3.95 \\
(15.13)\end{array}$ \\
\hline Year 1 since debt restructuring & $\begin{array}{l}-5.08 \\
(8.09)\end{array}$ & $\begin{array}{c}-25.30^{* *} \\
(10.00)\end{array}$ & $\begin{array}{c}-23.42^{* * *} \\
(7.99)\end{array}$ & $\begin{array}{l}-8.34 \\
(6.67)\end{array}$ \\
\hline Year 2 since debt restructuring & $\begin{array}{l}-6.43 \\
(8.33)\end{array}$ & $\begin{array}{c}-18.41^{*} \\
(10.45)\end{array}$ & $\begin{array}{c}-21.79^{* *} \\
(8.98)\end{array}$ & $\begin{array}{l}-9.31 \\
(8.89)\end{array}$ \\
\hline Year 3 since debt restructuring & $\begin{array}{l}-3.77 \\
(7.15) \\
\end{array}$ & $\begin{array}{l}-19.24^{*} \\
(10.05) \\
\end{array}$ & $\begin{array}{c}-19.88^{* *} \\
(10.03)\end{array}$ & $\begin{array}{l}-8.61 \\
(6.53) \\
\end{array}$ \\
\hline Index 1.1 & -3.40 & -4.67 & -1.91 & -4.67 \\
\hline Index 1.2 & $1.14^{* *}$ & 0.70 & -0.47 & $1.48^{* *}$ \\
\hline Index 2.1 & 2.45 & 2.02 & 1.96 & 3.35 \\
\hline Index 2.2 & -1.23 & -2.87 & -3.50 & 1.21 \\
\hline Index 2.3 & 0.01 & -1.13 & -1.60 & $2.15^{*}$ \\
\hline Index 3.1 & $5.12^{*}$ & $4.78^{* *}$ & $5.14^{* *}$ & 1.58 \\
\hline Index 4.1 & $2.53^{*}$ & 2.25 & 2.23 & 0.38 \\
\hline Index 4.2 & -0.14 & -2.85 & -0.48 & -2.39 \\
\hline Index 5.1 & 0.35 & $0.69^{* * *}$ & $0.50^{*}$ & $0.50^{* *}$ \\
\hline Index 6.1 & -5.51 & $-15.56^{* *}$ & $-12.91^{* * *}$ & $-8.23^{* *}$ \\
\hline Index 6.2 & 1.74 & $16.43^{* * *}$ & $8.79^{* *}$ & $8.60^{* *}$ \\
\hline Real exchange rate & $-6.63^{* *}$ & $-8.70^{* * *}$ & $-6.53^{* * *}$ & $-5.57 * * *$ \\
\hline Banking crisis indicator & -16.26 & $-20.56^{*}$ & -11.90 & -12.58 \\
\hline IMF agreement indicator & -10.21 & $-15.71^{* * *}$ & -4.59 & $-9.87^{*}$ \\
\hline Constant & $-43.21^{* *}$ & $-88.22^{* * *}$ & $-76.99 * * *$ & $-62.47^{*}$ \\
\hline Observations & 5504 & 5480 & 5442 & 5466 \\
\hline Adjusted $R^{2}$ & 0.17 & 0.19 & 0.17 & 0.18 \\
\hline
\end{tabular}

Dependent variable: total amount borrowed by sector in percentage deviations from the mean. Robust standard errors clustered on country are in parentheses.

Year and country fixed effects are included.

* significant at $10 \%$; * significant at $5 \%$; ** sisnificant at $1 \%$. 
Table 7: Effects of different types of restructuring

\begin{tabular}{|c|c|c|c|c|}
\hline & $(1)$ & $(2)$ & $(3)$ & $(4)$ \\
\hline Month renegotiations began & $\begin{array}{c}-5.07 \\
(14.28)\end{array}$ & $\begin{array}{c}-5.87 \\
(13.40)\end{array}$ & $\begin{array}{c}-6.07 \\
(14.24)\end{array}$ & $\begin{array}{c}-1.65 \\
(13.74)\end{array}$ \\
\hline \multirow[t]{2}{*}{ Renegotiations continue } & $\begin{array}{c}-16.60^{*} \\
(8.83) \\
\end{array}$ & $\begin{array}{c}-16.75^{*} \\
(9.58) \\
\end{array}$ & $\begin{array}{c}-15.57^{*} \\
(8.01) \\
\end{array}$ & $\begin{array}{l}-8.16 \\
(7.72) \\
\end{array}$ \\
\hline & $\begin{array}{l}\text { No buybacks } \\
\text { and swaps (a) }\end{array}$ & $\begin{array}{c}\text { No new } \\
\text { money (b) }\end{array}$ & $\begin{array}{l}\text { Official } \\
\text { (c) }\end{array}$ & $\begin{array}{l}\text { Intersection of } \\
\text { (a) (b) (c) }\end{array}$ \\
\hline Month of debt restructuring & $\begin{array}{c}-39.68^{* * *} \\
(11.24)\end{array}$ & $\begin{array}{l}-18.62 \\
(11.66)\end{array}$ & $\begin{array}{c}-44.60^{* * *} \\
(14.75)\end{array}$ & $\begin{array}{c}-33.5^{* * *} \\
(13.0)\end{array}$ \\
\hline Year 1 since debt restructuring & $\begin{array}{c}-41.10^{* * *} \\
(9.95)\end{array}$ & $\begin{array}{c}-28.54^{* * *} \\
(8.74)\end{array}$ & $\begin{array}{c}-46.44^{* * *} \\
(10.69)\end{array}$ & $\begin{array}{c}-43.6^{* * *} \\
(10.2)\end{array}$ \\
\hline Year 2 since debt restructuring & $\begin{array}{c}-29.22^{* * *} \\
(10.13)\end{array}$ & $\begin{array}{c}-29.66^{* * *} \\
(9.52)\end{array}$ & $\begin{array}{c}-28.64^{* * *} \\
(10.57)\end{array}$ & $\begin{array}{c}-37.3^{* * *} \\
(10.2)\end{array}$ \\
\hline \multirow[t]{2}{*}{ Year 3 since debt restructuring } & $\begin{array}{c}-26.62^{* *} \\
(11.08) \\
\end{array}$ & $\begin{array}{c}-28.84^{* * *} \\
(8.19) \\
\end{array}$ & $\begin{array}{c}-27.60^{* *} \\
(11.14) \\
\end{array}$ & $\begin{array}{c}-43.7^{* * *} \\
(11.0) \\
\end{array}$ \\
\hline & $\begin{array}{l}\text { Buybacks } \\
\text { and swaps }\end{array}$ & $\begin{array}{c}\text { New } \\
\text { money }\end{array}$ & Commercial & \\
\hline Month of debt restructuring & $\begin{array}{c}16.08 \\
(20.61)\end{array}$ & $\begin{array}{l}-15.53 \\
(12.65)\end{array}$ & $\begin{array}{c}-4.43 \\
(11.68)\end{array}$ & \\
\hline Year 1 since debt restructuring & $\begin{array}{c}10.44 \\
(12.48)\end{array}$ & $\begin{array}{l}-11.26 \\
(10.59)\end{array}$ & $\begin{array}{r}-10.57 \\
(8.08)\end{array}$ & \\
\hline Year 2 since debt restructuring & $\begin{array}{c}4.27 \\
(11.82)\end{array}$ & $\begin{array}{c}-23.47^{* * *} \\
(7.53)\end{array}$ & $\begin{array}{c}-16.01^{* *} \\
(7.15)\end{array}$ & \\
\hline Year 3 since debt restructuring & $\begin{array}{c}12.08 \\
(14.32)\end{array}$ & $\begin{array}{c}-27.86^{* * *} \\
(9.16) \\
\end{array}$ & $\begin{array}{c}-21.58^{* * *} \\
(5.78)\end{array}$ & \\
\hline Constant & $\begin{array}{c}-76.67^{* * *} \\
(19.96)\end{array}$ & $\begin{array}{c}-77.62^{* * *} \\
(20.83)\end{array}$ & $\begin{array}{c}-74.70^{* * *} \\
(20.78)\end{array}$ & $\begin{array}{c}-74.24^{* * *} \\
(21.95)\end{array}$ \\
\hline Observations & 5515 & 5515 & 5515 & 5515 \\
\hline Adjusted $R^{2}$ & 0.21 & 0.20 & 0.21 & 0.20 \\
\hline
\end{tabular}

Dependent variable: total amount borrowed in percentage deviations from the mean.

Robust standard errors clustered on country are in parentheses.

Year and country fixed effects and all control variables are included.

* significant at $10 \% ;{ }^{* *}$ significant at $5 \% ; * * *$ significant at $1 \%$. 
Table 8: Robustness tests

\begin{tabular}{|c|c|c|c|c|c|c|}
\hline & $\begin{array}{c}\text { Average size } \\
\text { of loan/issue } \\
(1)\end{array}$ & $\begin{array}{c}\text { Number } \\
\text { of loans/issues } \\
(2) \\
\end{array}$ & $\begin{array}{c}\text { National } \\
\text { currency } \\
(3) \\
\end{array}$ & $\begin{array}{c}\text { Year } \\
<1999 \\
(4)\end{array}$ & $\begin{array}{c}\text { Year } \\
<1991 \\
(5)\end{array}$ & $\begin{array}{c}\text { Year } \\
>1990 \\
(6)\end{array}$ \\
\hline $\begin{array}{l}\text { Month renegotiations } \\
\text { began }\end{array}$ & $\begin{array}{c}14.40 \\
(49.71)\end{array}$ & $\begin{array}{c}33.39 \\
(34.26)\end{array}$ & $\begin{array}{c}-5.40 \\
(16.04)\end{array}$ & $\begin{array}{c}-4.40 \\
(15.33)\end{array}$ & $\begin{array}{c}-16.05^{*} \\
(8.50)\end{array}$ & $\begin{array}{c}-9.75 \\
(27.44)\end{array}$ \\
\hline $\begin{array}{l}\text { Renegotiations } \\
\text { continue }\end{array}$ & $\begin{array}{c}-55.40^{* * *} \\
(13.11)\end{array}$ & $\begin{array}{l}-25.81^{*} \\
(15.30)\end{array}$ & $\begin{array}{c}-13.87^{* *} \\
(6.90)\end{array}$ & $\begin{array}{c}-14.81^{*} \\
(8.85)\end{array}$ & $\begin{array}{l}-4.74 \\
(4.68)\end{array}$ & $\begin{array}{c}-35.10^{* *} \\
(16.44)\end{array}$ \\
\hline $\begin{array}{l}\text { Month of debt } \\
\text { restructuring }\end{array}$ & $\begin{array}{c}-46.20^{* *} \\
(23.32)\end{array}$ & $\begin{array}{l}-47.76^{*} \\
(24.74)\end{array}$ & $\begin{array}{c}4.54 \\
(18.01)\end{array}$ & $\begin{array}{l}-21.42^{*} \\
(11.55)\end{array}$ & $\begin{array}{l}-5.83 \\
(8.88)\end{array}$ & $\begin{array}{l}-27.05 \\
(16.58)\end{array}$ \\
\hline $\begin{array}{l}\text { Year } 1 \text { since debt } \\
\text { restructuring }\end{array}$ & $\begin{array}{c}-35.58^{*} \\
(21.23)\end{array}$ & $\begin{array}{c}-48.44^{* * *} \\
(15.31)\end{array}$ & $\begin{array}{l}-18.91^{*} \\
(11.31)\end{array}$ & $\begin{array}{l}-20.13^{*} \\
(10.59)\end{array}$ & $\begin{array}{c}-5.44 \\
(10.10)\end{array}$ & $\begin{array}{c}-36.88^{* * * *} \\
(12.08)\end{array}$ \\
\hline $\begin{array}{l}\text { Year } 2 \text { since debt } \\
\text { restructuring }\end{array}$ & $\begin{array}{c}-52.92^{* * *} \\
(18.00)\end{array}$ & $\begin{array}{c}-40.23^{* *} \\
(17.40)\end{array}$ & $\begin{array}{l}-17.45 \\
(11.67)\end{array}$ & $\begin{array}{l}-12.12 \\
(11.45)\end{array}$ & $\begin{array}{l}-1.22 \\
(7.63)\end{array}$ & $\begin{array}{c}-28.01^{* *} \\
(11.04)\end{array}$ \\
\hline $\begin{array}{l}\text { Year } 3 \text { since debt } \\
\text { restructuring }\end{array}$ & $\begin{array}{c}8.67 \\
(26.24) \\
\end{array}$ & $\begin{array}{l}-19.03 \\
(26.44) \\
\end{array}$ & $\begin{array}{c}-18.43^{*} \\
(9.67) \\
\end{array}$ & $\begin{array}{r}-12.40 \\
(8.99) \\
\end{array}$ & $\begin{array}{c}-15.70^{* *} \\
(6.62) \\
\end{array}$ & $\begin{array}{c}-24.16^{* *} \\
(11.09)\end{array}$ \\
\hline Index 1.1 & 0.74 & -8.41 & -3.98 & -0.82 & -1.75 & $-7.17^{*}$ \\
\hline Index 1.2 & -0.18 & -0.23 & $1.80^{*}$ & -0.04 & 0.48 & 0.62 \\
\hline Index 2.1 & 6.74 & 3.15 & 3.14 & 1.12 & 0.78 & 4.37 \\
\hline Index 2.2 & $-7.19^{*}$ & $-6.22^{*}$ & -2.02 & -2.57 & 1.32 & -3.95 \\
\hline Index 2.3 & -4.41 & $-7.46^{*}$ & -0.66 & -3.16 & 2.52 & -2.32 \\
\hline Index 3.1 & $12.56^{* *}$ & $11.76^{* *}$ & $5.59^{* *}$ & $9.15^{* *}$ & -4.43 & $6.04^{*}$ \\
\hline Index 4.1 & $4.09^{*}$ & $5.55^{*}$ & -0.32 & $4.42^{* *}$ & 5.65 & 1.19 \\
\hline Index 4.2 & 1.07 & -4.14 & -3.20 & 1.91 & 1.58 & -2.61 \\
\hline Index 5.1 & $1.02^{* *}$ & $1.75^{* * *}$ & 0.39 & $0.78^{* * *}$ & 0.10 & $1.17^{* * *}$ \\
\hline Index 6.1 & -30.25 & $-29.95^{* * *}$ & $-20.95^{* * *}$ & $-51.26^{* * *}$ & -17.28 & $-15.63^{* *}$ \\
\hline Index 6.2 & $23.12^{*}$ & $38.57^{* * *}$ & $14.41^{* * *}$ & $37.66^{* * *}$ & 16.52 & $18.60^{* * *}$ \\
\hline Banking crisis & -15.89 & -18.19 & $-17.40^{* *}$ & $-16.73^{*}$ & $-16.41^{* * *}$ & -19.98 \\
\hline IMF agreement & -15.46 & -18.82 & $-12.91^{*}$ & -10.53 & 3.28 & $-20.28^{* * *}$ \\
\hline Real exchange rate & -0.55 & -9.07 & & $-15.18^{* * *}$ & 3.41 & $-10.27^{* *}$ \\
\hline Constant & -61.59 & -90.59 & -5.85 & $121.69^{* * *}$ & -31.93 & $-85.86^{* * *}$ \\
\hline Observations & 5826 & 5826 & 5962 & 4186 & 1697 & 3818 \\
\hline Adjusted $R^{2}$ & 0.05 & 0.06 & 0.22 & 0.25 & 0.11 & 0.17 \\
\hline
\end{tabular}

Dependent variables in percentage deviations from the mean.

Robust standard errors clustered on country are in parentheses.

Year and country fixed effects are included.

* significant at $10 \%$; ${ }^{*}$ significant at $5 \%$; ** significant at $1 \%$. 
Table 9: Data formats and sources

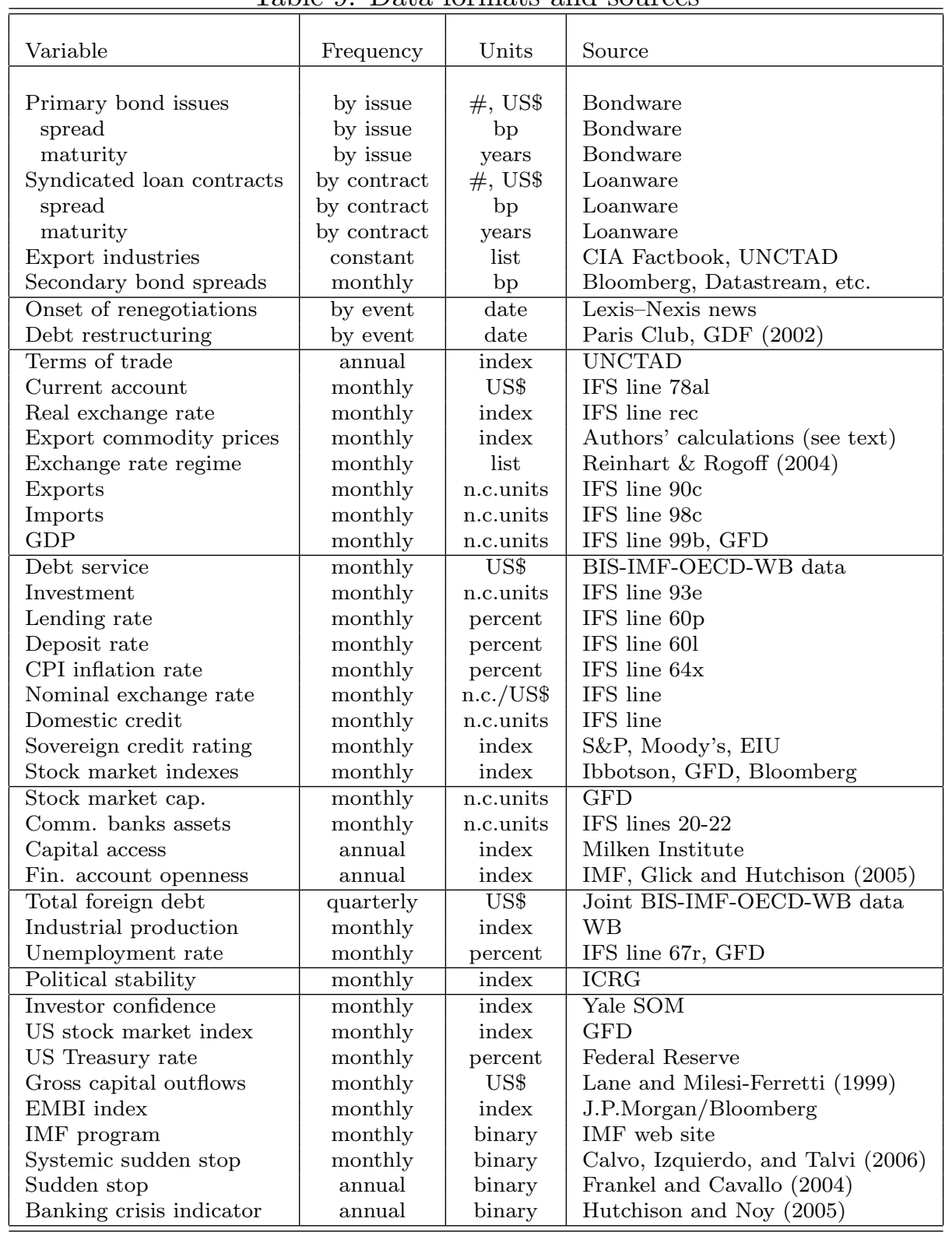

Note: See text for description of Bondware and Loanware, GDF is World Bank's Global Development Finance, IFS is International Financial Statistics, GFD is Global Financial Data, EIU is Economist Intelligence Unit, ICRG is International Country Risk Data. Most data sets are available through Yale University Library. 


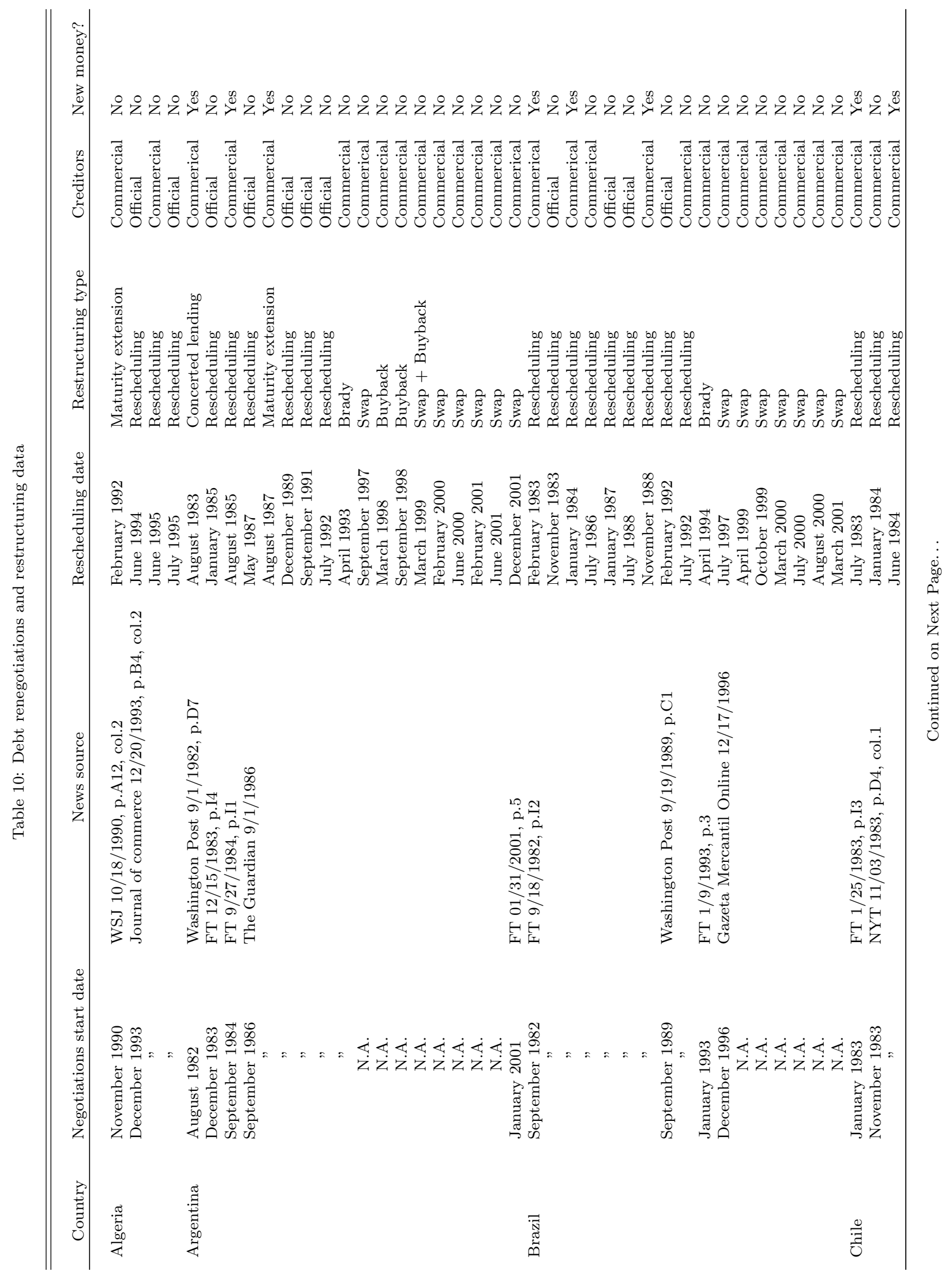




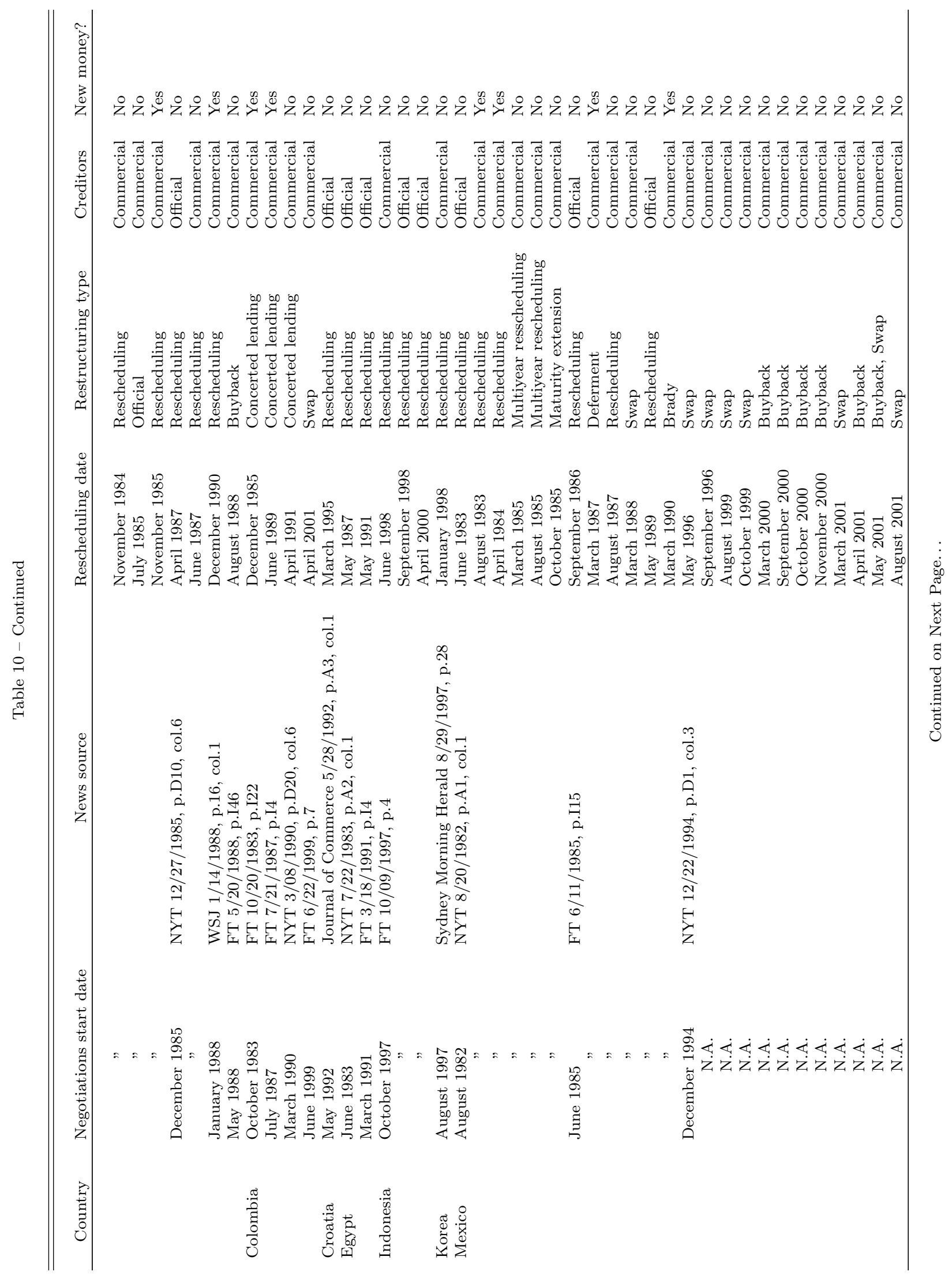




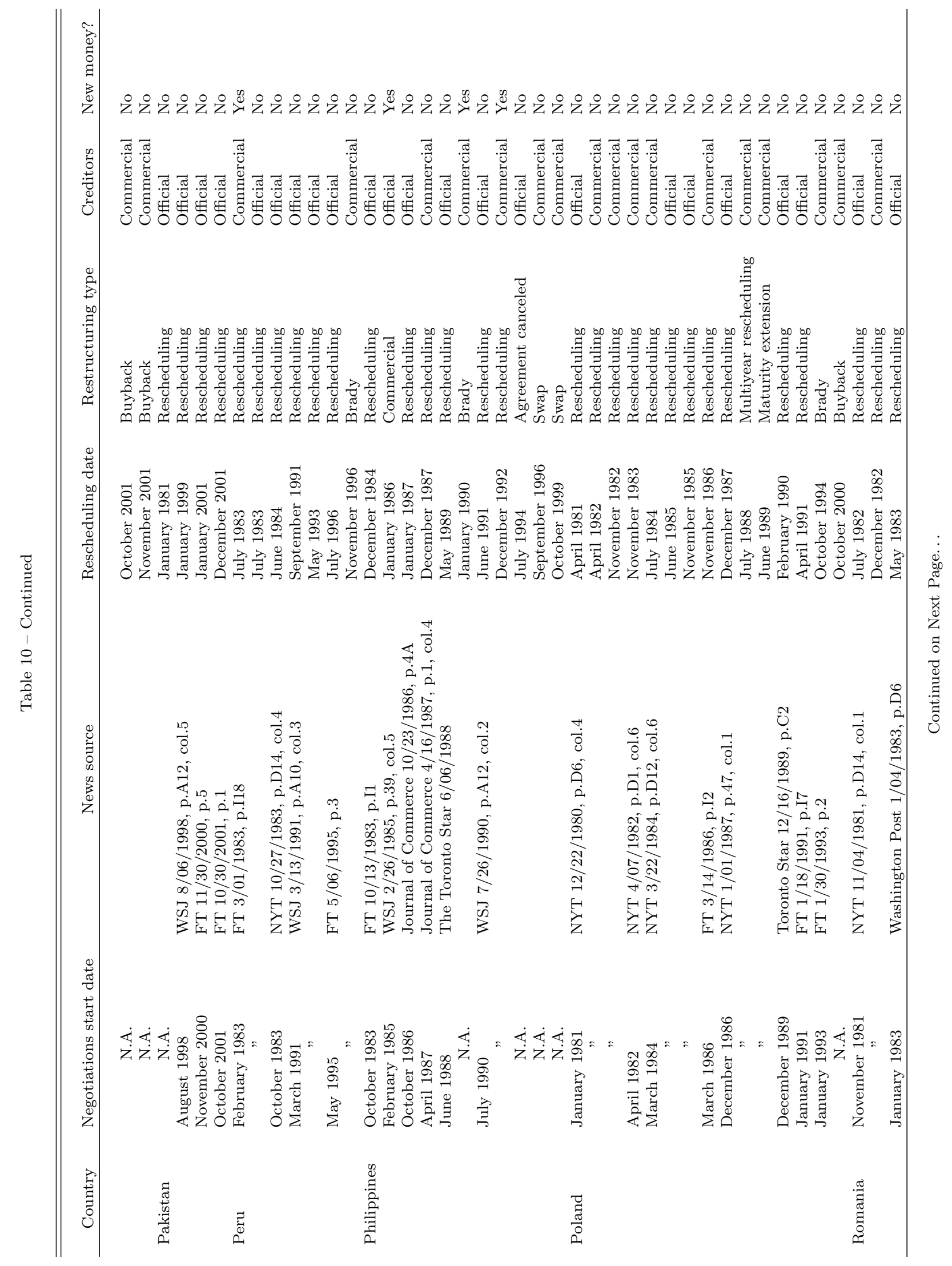




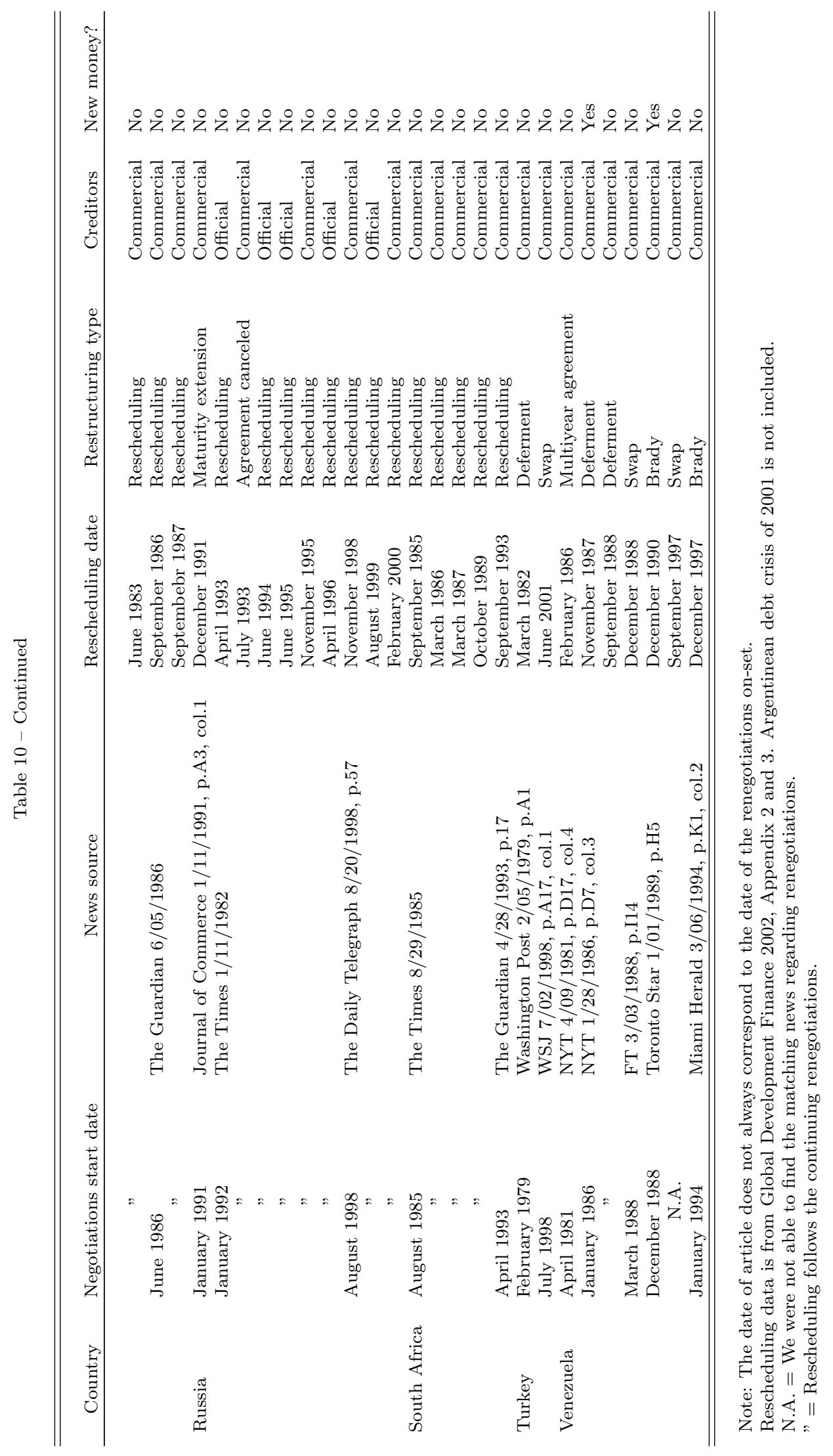

